\title{
Shifting Neighborhoods, Shifting Health: A Longitudinal Analysis of Gentrification and Health in Los Angeles County \\ Chinyere Agbai
}

\begin{abstract}
Gentrification is characterized by an influx of capital, built environment upgrades, and physical and social displacement of residents and institutions. The numerous, relatively rapid transitions that occur during gentrification make accounting for duration of exposure to gentrification particularly important when exploring its relationship to health. Though a large literature explores how timing and duration of exposure to relatively stable neighborhood conditions is linked to health, little is known about how exposure to gentrification is linked to the health of longtime residents. Using restricted, longitudinal data from the Los Angeles Family and Neighborhood Survey, I ask (1) how is duration of exposure to gentrification linked to the selfreported health of those who remain in the neighborhood? (2) How does this relationship vary for members of different racial and ethnic groups? Results indicate that the longer an individual lives in a gentrifying neighborhood, the better their self-reported health. The results do not vary by race or ethnicity. The results of this study are not an endorsement of the use of gentrification as a public health intervention, as previous work finds that gentrification can also be associated with social, physical, and institutional displacement, as well as heightened class-based and racial tensions. Instead, findings reiterate the importance of neighborhood investments for the health and wellbeing of their residents over time.
\end{abstract}




\section{INTRODUCTION}

From early works, such as The Philadelphia Negro (Du Bois 1899), through the Chicago School's exploration of urban development in concentric circles (Park et al. 1925), urban sociologists have long been concerned with the role of the neighborhood in reproducing inequality. More recent work underscores the extent of the residential segregation of American neighborhoods, which occurred as a result of federal and local policies, white flight, racial violence, and other factors that gave rise to racially segregated residential patterns (Massey and Denton 1993; Wilson 1987). Gentrification, or the influx of capital and upper-middle class residents into formerly disinvested urban neighborhoods (Smith 1996), provides an interesting example of neighborhood transition because it involves a reversal of the social order of space (Lefebvre 1991) in which higher-income, predominantly white residents occupied suburbs, while Black Americans, immigrants, and the poor were confined to central cities.

Local officials of the twenty-first century often promote implicitly pro-gentrification policies as a means by which to overcome depleted urban tax bases, concentrated poverty, and street crime in cities across the country. The Amazon Corporation's recent search for a second corporate headquarters provides one notable instance of how many localities are prepared to offer large tax incentives to attract corporations, often at the expense of affordable housing for existing residents (Casselman 2018; Wingfield 2018). Though gentrification is purported to serve as a solution to many urban problems (Newman and Wyly 2006; Smith 2002), numerous questions concerning its impacts on residents remain. For instance, it is not clear how the experience of living in a gentrifying neighborhood is related to the health of residents. The neighborhood upgrades, stress, and changes in neighborhood social networks and crime associated with gentrification may all impact health in potentially conflictual ways. Although 
gentrification may significantly impact both the physical and psychological health of residents, little research investigates this relationship.

Existing research on the relationship between gentrification and health employs crosssectional data, inhibiting our ability to understand how exposure to this process of neighborhood change manifests in health over time (Gibbons and Barton 2016; M. Huynh and Maroko 2014; Izenberg, Mujahid, and Yen 2018). In addition, despite a large literature concerning how the residential context and the timing and duration of exposure to neighborhood advantage or disadvantage affects residents (Jackson and Mare 2007; Kawachi and Berkman 2003; Sharkey and Elwert 2011; Wodtke, Harding, and Elwert 2011), little is known about how duration of exposure to this particular set of changing neighborhood conditions is linked to the health of residents. A longitudinal framework is necessary to fully comprehend the relationship between gentrification and health, both because some residents experience this changing set of neighborhood conditions for many years, and because the effects may differ in the short and long terms.

Drawing on longitudinal data and up to 17 years of residential histories for more than 2,000 adults sampled in the Los Angeles Family and Neighborhood Survey (L.A. FANS), in addition to decennial Census data, I examine two questions. First, how is duration of exposure to gentrification linked to the self-reported health of residents? Second, how does this relationship vary for members of different racial and ethnic groups? Results indicate that the longer an individual lives in a gentrifying neighborhood, the better their self-reported health. These results are not driven by a particular racial or ethnic group. These findings have important implications for policy, and suggest that if longtime residents are to reap the health benefits of the 
neighborhood improvements that accompany gentrification, efforts must be made to allow these residents to remain in their neighborhoods as they undergo change.

\section{LITERATURE REVIEW}

\subsection{The Link Between Gentrification And Health}

Gentrification is a process of neighborhood transition that involves upgrades to the built environment in formerly disinvested neighborhoods; an influx of higher-income, predominantly white residents; and direct or indirect displacement of those who earn low incomes (Glass 1964; Hammel and Wyly 1996; Smith 1996). Understanding gentrification through Lefebvre's (1991) concept of "social space" provides one lens through which to conceptualize the link between gentrification and both physical and mental health. He argues that space is not simply the backdrop of social life, but rather a "means of control, and hence of domination, of power" (1991:26). Beginning in the 1940s, the spatial power relationship in metropolitan areas across the United States was one in which whites resided in the suburbs, while Black Americans, other People of Color, and the poor were confined to increasingly crowded urban neighborhoods (Connolly 2014; Korver-Glenn 2018; Massey and Denton 1993; Pager and Shepherd 2008). Gentrification involves a shift in the spatial hierarchy in which capital, as well as white residents and those of higher socioeconomic status, are increasingly concentrated in urban neighborhoods, while Black Americans and immigrants are displaced to suburbs with rising levels of poverty (For review, see Lacy 2016). In the face of the shifting spatial power relations that characterize gentrification, it is unclear the extent to which the health of longtime residents of these transitioning neighborhoods might be affected.

One way that gentrification may impact both mental and physical health is through its effects on place-based social networks (Fullilove 2016). Those with place-based social networks 
experience better psychological and physical health than their more isolated counterparts, largely because of the material aid, emotional support, information, and services that these networks provide (Caplan 1974; Cassel 1976; Cohen and McKay 1984; House, Landis, and Umberson 1988; Kawachi and Berkman 2003; Klinenberg 2003). Gibbons, Barton, and Reling (2019) find that on average, residence in a gentrifying neighborhood is associated with lower community connections. To the extent that displacement splinters neighborhood social networks, this may negatively impact both mental and physical health over time.

A second way that gentrification may negatively affect self-reported health is by inducing stress among longtime residents. An important stressor among longtime residents in gentrifying neighborhoods is that of displacement, or the fear of it. A vibrant debate exists concerning the extent to which gentrification displaces longtime residents. Some scholars find little displacement (Ellen and O’Regan 2011; Freeman 2005; Freeman and Braconi 2004), while others find more substantial levels (Martin and Beck 2016; Newman and Wyly 2006). In her review of the gentrification literature, Brown-Saracino (2017) argues that conclusions about displacement in gentrifying neighborhoods fall broadly along methodological lines, with qualitative researchers finding physical, political, and cultural displacement of longtime residents and institutions. Conversely, quantitative scholars often find little or no displacement of lowincome residents. Within quantitative scholarship, however, the operationalization of displacement matters immensely for conclusions about the extent of displacement in gentrifying neighborhoods (Carlson 2020). Though it is unclear the extent to which longtime residents experience physical displacement, Gibbons (2019) argues that these residents may experience "anticipatory stress" as a result of the fear that they may be displaced (Freeman 2006; Hicken, Lee, and Hing 2018). 
The stress of living in a gentrifying neighborhood may be particularly acute among residents of color. There is some disagreement about the extent to which Black and Hispanic ${ }^{1}$ neighborhoods are more or less likely to gentrify than white neighborhoods. Some find that lowincome Black and Hispanic neighborhoods are more likely to experience gentrification (Ellen and O'Regan 2008), while others find that these neighborhoods are in fact less likely to experience this kind of neighborhood transition (J. Hwang and Sampson 2014). In New York, Sutton (2018) finds that those moving into gentrifying neighborhoods are disproportionately white, although Pattillo (2008) documents notable cases of Black gentrification in Chicago. In the Black and Hispanic neighborhoods that do gentrify, this process of neighborhood change often facilitates racial tension in addition to the class-based tension that arises as housing costs rise and neighborhood businesses are replaced with higher-end establishments (Anderson 1997; Sullivan and Shaw 2011; Zukin 2011). This racial tension manifests in the use of law enforcement to police the behavior of Black and Hispanic residents (Freeman 2006; Logan and Molotch 1987), and attempts to rebrand the neighborhood to distance it from the low-income People of Color who originally resided there (Hwang 2016; Hyra 2017; Sullivan and Shaw 2011; Zukin 2011). In Philadelphia, Gibbons (2019) finds that an influx of white residents in particular is correlated with greater than average stress in gentrifying neighborhoods. Because stress is positively associated with a range of adverse health outcomes, from the common cold to coronary artery disease (Krantz and McCeney 2002; Morenoff 2003), increased stressors in gentrifying neighborhoods may prove particularly detrimental to both the mental and physical health of longtime Black and Hispanic residents over time.

Conversely, gentrification may be positively linked to health in four important ways. First, neighborhood upgrades, such as sidewalk or playground repairs, reduce the probability of 
accidents (Ellen, Mijanovich, and Dillman 2001). This may result in improved physical health over time. Moreover the construction of new grocery stores increases proximity to healthy food, which may then translate into improved diet among residents (Anguelovski 2015). Second, changes in crime may have mixed effects on self-reported health in gentrifying neighborhoods. Gentrification is associated with lower rates of homicide on average, but increased robberies in Black neighborhoods (Papachristos et al. 2011). Moreover, spatial context plays an important role in crime in gentrifying neighborhoods. In Los Angeles, gentrifying neighborhoods surrounded by communities not currently experiencing gentrification suffer more aggravated assaults than gentrifying neighborhoods surrounded by communities also experiencing this process of neighborhood change (Boggess and Hipp 2016). Changes in crime in gentrifying communities may therefore impact the health of residents in opposite directions. On the one hand, crime and violence have been linked to increased drug use and reduced infant birthweight (Boardman et al. 2001; Morenoff 2003). As a result, declines in homicides may positively impact physical, as well as mental, health. However, the uptick in robberies in Black gentrifying neighborhoods and aggravated assault in upgrading communities surrounded by stable, lowincome communities may negatively impact health.

Third, because neighborhood affluence is associated with higher self-rated health, even after controlling for individual-level characteristics (Browning, Cagney, and Wen 2003; Wen, Browning, and Cagney 2003), the rise in neighborhood socioeconomic status that characterizes gentrification may result in better health among longtime residents. Finally, residents who remain in gentrifying neighborhoods often report increased neighborhood satisfaction as a result of the increased commercial activity in the formerly disinvested neighborhood (Ellen and O’Regan 2011; Freeman 2006). This increased neighborhood satisfaction may then lead to gains 
in psychological health. This body of literature, then, suggests that a broad array of forces may act to produce conflictual self-reported health outcomes among longtime residents in gentrifying neighborhoods.

\subsection{Duration Of Exposure to Neighborhood Context}

A longitudinal framework is necessary to fully comprehend the link between gentrification and health, both because some residents experience this relatively turbulent set of neighborhood conditions for many years, and because the relationship may differ in the short and long terms (for review, see Hyra et al. 2019). Gibbons and Barton (2016) find that on average, self-reported health improves for residents of gentrifying neighborhoods. For Black residents, however, this relationship is negative (Gibbons and Barton 2016; Izenberg et al. 2018). Huynh and Maroko (2014) find that living in a gentrifying tract is associated with greater odds of preterm birth among Black residents, but lower odds among whites. Though these studies provide important insight into the relationship between gentrification and health, their use of crosssectional data inhibit our ability to understand how exposure to this process of neighborhood change accumulates in the bodies of individuals and manifests over time. As a result, attention to duration of exposure is crucial to understanding how gentrification is associated with a variety of outcomes, including health.

Extant research demonstrates the link between early life exposure to neighborhood-level disadvantage and low academic achievement and health outcomes (Jackson and Mare 2007; Sampson, Sharkey, and Raudenbush 2008; Sampson and Winter 2016; Sharkey and Elwert 2011; Wodtke et al. 2011). The impact of the neighborhood context on a range of individual-level outcomes does not end with childhood, however. Persistent exposure to childhood neighborhood 
disadvantage has also been linked to poor mental health (Wheaton and Clarke 2003) and cognitive ability (Sharkey and Elwert 2011) later in life. Wodtke and colleagues (2011) underscore the importance of duration of exposure in neighborhood effects research because these effects are often cumulative and/or lagged, making the use of neighborhood conditions at one time point insufficient to understand individual-level outcomes. Moreover, because children often reside in the same kinds of neighborhoods during adulthood as their parents and grandparents did (Sharkey 2013), the impacts of exposure to a particular kind of neighborhood context both accumulate throughout the life course and are passed to the next generation (Clarke et al. 2013; Sampson 2012; Sharkey and Faber 2014). This is evidenced by the fact that the children and grandchildren of adults who grew up in disadvantaged neighborhoods experience reduced academic achievement (Sharkey and Elwert 2011) and worse health outcomes (Sharkey 2013). This body of literature, then, suggests that both characteristics of the residential context and duration of exposure to a particular kind of neighborhood are crucial to understanding the ways in which the neighborhood affects individuals over and above individual- and family-level characteristics.

The gentrifying neighborhood offers an opportunity to explore not only neighborhood effects on health but also the ways in which duration of exposure to a changing neighborhood context is linked to health. The gentrifying neighborhood creates two important groups in terms of duration of exposure and residential context. One group is comprised of those who remain in the neighborhood from the earlier stages of gentrification through the later stages.

Neighborhoods in the early stage of gentrification are characterized by disinvestment and are populated by residents who earn low incomes and often are also Black and Hispanic. Conversely, neighborhoods in the late stage of gentrification experience increased capital investment as well 
as an influx of whites and those of higher socioeconomic status (Hwang and Sampson 2014; Wyly and Hammel 2004). The health of those who live in a neighborhood for many years as it moves from the early to late stages of gentrification may differ substantially from those who reside in these neighborhoods for shorter time periods. Longtime residents may experience whatever negative effects that come from living in a more disinvested neighborhood in the early stages of gentrification, as well as any stress and social network fracturing that may occur during the longer term. By the late stage of gentrification, these same residents may also reap the benefits of neighborhood upgrades that come at this stage.

Conversely, those who live in gentrifying neighborhoods for short periods of time experience only one stage, or parts of multiple stages, and the associated health effects. For instance, those living in a neighborhood for just a few years during the early stage of gentrification would not experience the full range of residential contexts that comes with living in a gentrifying neighborhood for many years. Consequently, these individuals may experience different health outcomes than those who live in gentrifying neighborhoods for long periods of time and were therefore exposed to a wider range of neighborhood characteristics. Those who remain in gentrifying neighborhoods as they transition present an interesting group because they have experienced the longest duration of exposure to gentrification. These longtime residents may experience both the positive health effects of increased neighborhood amenities and reduced homicides, in addition to the negative impact of a reduced sense of community, stress, and higher incidence of burglary. Looking specifically at duration of exposure to gentrification provides insight into the extent of neighborhood change that an individual has experienced. Because gentrification provides a range of residential contexts in a relatively short period of time, it is 
important to take into account not only whether one has experienced gentrification, but for how long.

Extant literature sets up a conflicting set of hypotheses concerning how health may change as individuals live in gentrifying neighborhoods for longer durations. On the one hand, fracturing social networks, stress concerning displacement, and increased policing of Black and Hispanic residents may result in declining health with greater duration of exposure to gentrification. Conversely, repairs to the built environment, lower rates of homicide, and greater access to neighborhood amenities may be linked to greater physical and mental health.

Though a large body of work explores how neighborhoods affect individuals when the residential context is relatively stable, much less is known about how the simultaneous and relatively rapid transitions that characterize gentrification are linked to individual-level health. In this study, I endeavor to not only demonstrate the link between gentrification and health, but also to explore how this relationship changes with time. Drawing on detailed longitudinal data and residential histories of nearly 2,000 adults sampled in the Los Angeles Family and Neighborhood Survey, I ask, (1) how is duration of exposure to gentrification linked to the self-reported health of those who remain in the neighborhood? (2) How does this relationship vary for members of different racial and ethnic groups?

\section{LOS ANGELES COUNTY AS A CASE OF GENTRIFICATION}

Los Angeles (LA) County provides an important case study of gentrification for three reasons. First, LA County is diverse, as nearly half of its residents identify as Hispanic. NonHispanic whites account for 26 percent of the population, 15 percent are Asian, and 9 percent are Black (U.S. Census Bureau 2018). Because Hispanics are the second fastest-growing ethnic group in the country after Asians (Colby and Ortman 2015), Los Angeles-based research 
provides important insight into the racial dynamics of gentrification in a city with significant racial diversity. Second, while cities like New York, Philadelphia, and Chicago are the focus of many gentrification studies (Ding, Hwang, and Divringi 2016; Gibbons and Barton 2016; Gibbons et al. 2019; Mary Huynh and Maroko 2014; Hwang and Sampson 2014; Timberlake and Johns-Wolfe 2016), fewer works focus on locations like Los Angeles (Izenberg et al. 2018). Gentrification in Los Angeles may be distinct from gentrification in east coast and midwestern cities like New York and Chicago because of the large proportion of single-family homes and its geographically sprawling metropolitan area (Chiland 2018; Woetzel et al. 2019). As a result, studying Los Angeles diversifies our understanding of urban environments and may also generate findings that are applicable to relatively similar cities, such as Phoenix and Houston.

Third, LA County has been in the throes of an affordable housing crisis for decades. Affordable housing options have declined since the 1990s as federal and local governments have increasingly relied upon the private sector to provide housing for the poor and working class. This, in combination with homeowner opposition to the construction of multi-family units in neighborhoods zoned for single-family homes, has contributed to the affordable housing shortage that has worsened in Los Angeles throughout the $21^{\text {st }}$ century (Davis 2006). Nearly 60 percent of renters in LA cannot afford their rent (Barragan 2015), and the median home price has nearly tripled between 1970 and 2018 (Khouri 2018). A shortage of affordable housing is linked to gentrification because the lack of affordable homes puts pressure on not only those who earn low incomes, but also on the middle- and upper-middle classes. As housing becomes increasingly expensive, those who earn higher incomes look to lower-income neighborhoods, contributing to the process of gentrification. Though the lack of affordable housing is particularly severe in Los Angeles, it is not a problem unique to this metropolitan area. In cities across the country, the lack 
of affordable housing is becoming increasingly dire, as increases in the cost of rent have outpaced income growth since 2001 (Currier et al. 2018). Exploring how gentrification unfolds in Los Angeles County will provide important insights for metropolitan areas that are experiencing the effects of their own local affordable housing crises. For these reasons, Los Angeles provides an important case study for understanding how the health of residents in gentrifying neighborhoods unfolds over time.

\section{DATA AND METHODS}

\subsection{Data}

Data for this study come from two sources. The first is the Los Angeles Family and Neighborhood Survey (L.A.FANS), which provides longitudinal data on individuals and families. Enumerated by the RAND corporation, L.A.FANS is a multilevel survey that employs a stratified sampling strategy to sample neighborhoods, block groups within neighborhoods, families within blocks, and children and adults within families. This survey employs a stratified sampling design in an effort to oversample poor and very poor neighborhoods and families with children in Los Angeles County. The survey, however, includes neighborhoods across the income distribution. L.A.FANS collects detailed longitudinal data on neighborhoods, families, children, residential choice, and neighborhood change. The first wave of responses was collected between 2000 and 2002 and the second between 2006 and 2008. The focus of this analysis is the adults sampled in this survey.

One important element of the restricted version of the L.A.FANS is the geocoded residential history calendar. This residential history details respondents' census tracts of residence for each year beginning from as far back as 1990 (Sastry et al. 2006). Although 
residential histories require recall, and therefore may introduce measurement error, this approach is widely employed (Desmond, Gershenson, and Kiviat 2015; Frank and Bjornstrom 2011; Rosenblatt and Cossyleon 2018; Sharkey and Elwert 2011) and provides important insight into the total number and location of neighborhoods in which respondents have resided.

The response rate in the portion of the L.A.FANS in which adults provide information about themselves and their households is 89 percent (Sastry et al. 2006). Of those who do respond to the survey, 9 percent of observations are missing. Rather than drop individuals with missing observations, I use multiple imputation (10 imputations performed in Stata 14), which uses chained equations to iteratively estimate missing values in both independent and dependent variables. This method is particularly well-suited to this analysis because it accommodates arbitrary missing-value patterns (Allison 2002; White, Royston, and Wood 2011). Because of the particularity of Los Angeles neighborhoods however, I do not impute missing census tracts in the residential histories. Results hold when analyses are performed on unimputed data, however. ${ }^{2}$ The final sample includes adults who completed the residential history calendar at wave 1 $(\mathrm{N}=1,141)$ and wave $2(\mathrm{~N}=2,024)$.

The second data source that this study draws upon is data from the U.S. Census Bureau. Specifically, I employ decennial census data from 1990, 2000, and 2010 from the Longitudinal Tract Database (Logan, Xu, and Stults 2014). Although the L.A.FANS lists the census tracts where respondents have resided, it does not provide detailed characteristics of the tracts. The Census data, therefore, provide insight into the sociodemographic composition of the neighborhoods that LA.FANS respondents list in their residential histories. These tract-level characteristics provide the basis for the measure of gentrification applied in this analysis, which is discussed in greater detail in the Measures section. I deploy linear interpolation to estimate 
tract characteristics in non-census years (Crowder and South 2008; Warner 2016). Gentrification researchers often employ decennial census data and/or ACS estimates alone as important elements of their gentrification measures (Ellen and O'Regan 2011; Martin and Beck 2016; Timberlake and Johns-Wolfe 2016). However, the use of linear interpolation more dynamically captures this process of neighborhood change and allows me to measure the number of years an individual has experienced gentrification.

To account for changes in census tract boundaries that often occur from one census to the next, I use census data standardized to 1990 boundaries from the Longitudinal Tract Database (Logan, Xu, and Stults 2014). Like many urban scholars, I use the census tract as a measure of the neighborhood. Census tracts typically include between 2,500 and 8,000 individuals. The U.S. Census Bureau employs local history and insights from local officials in an effort to construct census tracts that effectively approximate neighborhood boundaries (White 1987). Although the census tract is an imperfect representation of the neighborhood, in Los Angeles, census tracts are moderately sized, with approximately 5,600 residents per tract. Los Angeles tracts are also geographically compact, and undivided by large geographic boundaries, such as highways, large boulevards, and parks (Sastry et al. 2006:1009).

\subsection{Measures}

\subsubsection{Self-reported health}

The outcome variable in this analysis is overall, self-reported health. Respondents are asked, "what is your health in general?" in both waves of the survey. This measure of selfreported health is ordinal, and responses fall into one of five categories: $1=$ poor, $2=$ fair, $3=$ good, $4=$ very good, and $5=$ excellent. This kind of self-reported health data is widely used among social scientists (Browning and Cagney 2002; Gibbons 2019; Izenberg et al. 2018), 
reliable over time, and has been found to accurately reflect morbidity and mortality, as well as the mental health of respondents (Ferraro and Farmer 1999; Idler and Benyamini 1997). Capturing both mental and physical health is important in a study of gentrification and health because, as is highlighted elsewhere in this paper, gentrification may be related to both categories of health outcomes.

\subsubsection{Gentrification}

The primary independent variable is the total number of years a respondent has lived in a gentrifying census tract by waves 1 and 2 . In this analysis, a tract is said to be experiencing gentrification during a given year if it meets two criteria. First, the census tract must be "gentrifiable," meaning that its median household income and percent of residents age 25 and older with a college degree were both below their respective medians in Los Angeles County in 1990 (Ding et al. 2016; Gibbons and Barton 2016; Hammel and Wyly 1996; J. Hwang and Sampson 2014). This "threshold" requirement captures the previous disinvestment that is central to the definition of gentrification deployed in this analysis. ${ }^{3}$ Second, I adopt Ding, Hwang, and Divringi's (2016) metric, which asserts that a tract is undergoing gentrification if it is (a) gentrifiable and (b) the tract median rent and percent of those with college degrees increases by more than the county-wide increase since the previous year. A tract is also said to be gentrifying if it is (a) gentrifiable and (b) the median home value and percent with a college degree increased by more than the countywide increase that year. ${ }^{4}$

This measure reflects several important elements of gentrification. First, the housing measures capture changes in investment and amenities in the neighborhood. The use of either increasing rents or home values also demonstrates changing levels of affordability in formerly disinvested neighborhoods. The share of college graduates included in this measure represents an 
influx of those of higher socioeconomic status who may or may not initially earn high incomes (Ding et al 2016; Freeman 2005).

The gentrification variable indicates the number of years a respondent lived in any gentrifying tract at the time of the first and second interviews. This variable measures total exposure to gentrification and therefore includes the total number of years a respondent has lived in one or more gentrifying tracts. ${ }^{5}$ This measure of gentrification relies on annual increases in tract-level variables, and therefore the first year that a tract could have experienced gentrification is 1991. As a result, the maximum number of years of exposure to gentrification is 17 years, between 1991 and 2008. The relationship between health and moving out of gentrifying neighborhoods is an extremely important question, however the sample of residents who move out of gentrifying neighborhoods is too small in the L.A. FANS to investigate in this analysis. Because urban scholars operationalize gentrification using numerous different measures, I explore the extent to which the results are robust to alternate ways of measuring gentrification. Results using this alternate measure are similar in direction and magnitude. ${ }^{6}$

\subsubsection{Covariates}

The second important independent variable is race and ethnicity. In light of the array of stressors Black and Hispanic residents face in gentrifying neighborhoods discussed elsewhere in this manuscript (Anderson 1997; Freeman 2006; Logan and Molotch 1987; Sullivan and Shaw 2011; Zukin 2011), the health of residents may vary significantly by race. I therefore include a measure of race and ethnicity in the models. Categories include non-Hispanic Black, nonHispanic white, and Hispanic. Because the number of respondents who identify as non-Hispanic Asian, Native American, Pacific Islander, and other is relatively small in the L.A.FANS, I collapse these groups into the Asian/other category. 
Control measures from the L.A. FANS include individual-level educational attainment, annual income, sex, age, and binary variables indicating marital status and presence of children in the household. These variables are collected at 2 waves over the duration of the survey. I do not control for tract characteristics because this would hold constant precisely the kind of neighborhood change that this analysis seeks to capture. ${ }^{7}$

\subsection{Analytic Strategy}

This analysis is conducted in two parts. First, I present descriptive characteristics of the census tracts and adults included in the L.A.FANS sample. This step illuminates the extent to which the operationalization of gentrification applied in this analysis captures the social and demographic shifts described in the literature. Second, I explore the extent to which changes in duration of exposure to gentrification are linked to self-reported health. In this step, I pool observations from both waves of the L.A.FANS to estimate individual fixed effects models. The Hausman Test supports the use of fixed effects models over random effects. Fixed effects models estimate how changes in the duration of exposure to gentrification are associated with changes in health within individuals over time. One primary benefit of the fixed effects model is that it controls for time-invariant, unobserved characteristics at the individual level, such as childhood advantage or disadvantage and genetics, that may impact health over time. These models, therefore, are identified from variation within individuals across waves. Controlling unobserved, fixed characteristics that may predict health reduces the omitted variables bias that regularly plagues OLS. Although this analysis controls for fixed, unobserved characteristics of individuals, it cannot control for unobserved, time-varying, individual-level variables that may be associated with both health and gentrification. For example, as the tract undergoes change, residents may become more or less likely to walk outside. This change in behavior in gentrifying 
neighborhoods may have important ramifications for health (Allison 2009). This model is summarized in Equation 1,

$Y_{i j t}=B_{0}+B_{1}$ Gent $_{i j t}+B_{2}$ Gent $_{i j t}$ X Race $_{i j t}+B_{3}$ Individual $_{i j t}+u_{i j t}+\theta_{i}$,

where for each individual $\mathrm{i}$ in census tract $\mathrm{j}$ during wave $\mathrm{t}$, I model health $(Y)$ as a function of the total number of years an individual has resided in a gentrifying tract (Gent); an individual's race (Race); the interaction between the duration of exposure to gentrification and race (Gent x Race); and individual-level covariates (Individual). The individual-level error term is $u{ }^{8}$

The individual-level fixed effect $(\theta)$ holds constant the characteristics of individuals that do not vary over time, such as race and sex. Therefore, the main effects of race and sex have been differenced out of this interaction model, but the interaction between race and duration of exposure to gentrification remains (Gent $x$ Race). The duration of gentrification measure and remaining covariates included in Individual vary enough from wave 1 to wave 2 to be included in this fixed effects model. ${ }^{9}$ This analysis makes use of the survey weights provided by

\section{LA.FANS.}

\section{RESULTS}

\subsection{Descriptive Statistics}

Table 1 provides descriptive statistics for the census tracts in which L.A. FANS residents reside for the years between $1992^{10}$ and 2008. As is customary in many studies of gentrification, I have divided the descriptive statistics into 3 categories: gentrifying, gentrifiable, and not gentrifiable (Ding et al. 2016; Hammel and Wyly 1996; Timberlake and Johns-Wolfe 2016). The gentrifying category includes tracts that are found to be gentrifying as defined above. 
Gentrifiable tracts are those that met the disinvestment threshold of gentrifiability in 1990, but were not gentrifying. Non-gentrifying tracts are those that are were not gentrifiable and were not gentrifying in the given year. 
Table 1: Neighborhood-Level Means Descriptive Characteristics 1992-2008

\begin{tabular}{|c|c|c|c|c|c|c|c|c|c|}
\hline & \multicolumn{2}{|l|}{1992} & \multicolumn{3}{|c|}{2008} & \multicolumn{4}{|c|}{$\%$ Change 1992-2008 } \\
\hline & Gentrifying & Gentrifiable & $\begin{array}{l}\text { Not } \\
\text { Gentrifying }\end{array}$ & Gentrifying & Gentrifiable & $\begin{array}{l}\text { Not } \\
\text { Gentrifying }\end{array}$ & Gentrifying & Gentrifiable & $\begin{array}{l}\text { Not } \\
\text { Gentrifying }\end{array}$ \\
\hline \multirow[t]{2}{*}{ Rent } & 516.7 & 709.0 & $1,395.6$ & $1,141.3$ & $1,025.9$ & $2,569.7$ & 120.9 & 44.7 & 84.1 \\
\hline & $(104.3)$ & (195.7) & $(575.0)$ & $(415.0)$ & $(393.6)$ & $(1,802.6)$ & 297.9 & 101.1 & 213.5 \\
\hline \multirow[t]{2}{*}{ Home Value } & $155,766.1$ & $196,952.9$ & $515,180.0$ & $376,702.3$ & $285,149.7$ & $887,186.2$ & 141.8 & 44.8 & 72.2 \\
\hline & $(37,047.8)$ & $(55,542.0)$ & $(271,511.9)$ & $(112,851.9)$ & $(89,761.6)$ & $(620,255.6)$ & 204.6 & 61.6 & 128.4 \\
\hline \multicolumn{10}{|c|}{ Median Household } \\
\hline \multirow[t]{2}{*}{ Income } & $47,728.4$ & $52,943.9$ & $168,230.7$ & $47,924.1$ & $44,664.4$ & $148,568.1$ & 0.4 & -15.6 & -11.7 \\
\hline & $(20,476.8)$ & $(15,405.2)$ & $(115,062.3)$ & $(14,818.4)$ & $(13,783.6)$ & $(109,959.3)$ & -27.6 & -10.5 & -4.4 \\
\hline \multirow[t]{2}{*}{$\%$ College } & 4.1 & 6.4 & 30.1 & 9.7 & 7.6 & 30.9 & 136.6 & 18.7 & 2.7 \\
\hline & $(3.6)$ & $(4.1)$ & $(18.2)$ & $(5.7)$ & $(4.9)$ & (19.4) & 58.3 & 19.5 & 6.6 \\
\hline \multirow[t]{2}{*}{$\%$ White } & 3.8 & 12.4 & 52.2 & 6.6 & 8.9 & 36.9 & 73.7 & -28.2 & -29.3 \\
\hline & $(5.4)$ & (14.1) & $(25.1)$ & $(9.2)$ & $(9.9)$ & $(25.4)$ & 70.4 & -29.8 & 1.2 \\
\hline \multirow[t]{2}{*}{$\%$ Black } & 21.2 & 15.6 & 7.4 & 14.3 & 8.6 & 6.0 & -32.5 & -44.9 & -18.9 \\
\hline & $(19.2)$ & $(17.5)$ & $(10.4)$ & (14.8) & $(9.5)$ & (6.6) & -22.9 & -45.7 & -36.5 \\
\hline \multirow[t]{2}{*}{$\%$ Hispanic } & 72.8 & 66.1 & 27.0 & 72.7 & 77.0 & 39.1 & -0.1 & 16.5 & 44.8 \\
\hline & $(16.5)$ & $(16.8)$ & $(24.4)$ & $(14.5)$ & (14.1) & $(27.0)$ & -12.1 & -16.1 & 10.7 \\
\hline \multirow[t]{2}{*}{$\%$ Asian } & 1.7 & 5.6 & 12.8 & 5.9 & 5.0 & 17.6 & 247.1 & -10.7 & 37.5 \\
\hline & $(3.2)$ & $(6.2)$ & $(8.7)$ & $(6.7)$ & $(6.0)$ & (14.3) & 109.4 & -3.2 & 64.4 \\
\hline Total Tracts & 77 & 154 & 247 & 557 & 401 & 1073 & 623 & 160 & 334 \\
\hline
\end{tabular}

Note: Standard Deviations in Parentheses. All dollar amounts are standardized to 2012. 
Many of the observed tract-level changes in Table 1 align well with existing literature on gentrification. For instance, by 2008 median rent in gentrifying tracts had more than doubled. ${ }^{11}$ Similarly, median home value in gentrifying tracts increases by 142 percent, while it increased by much less in gentrifiable (45 percent) and non-gentrifying tracts ( 72 percent). Moreover, the share of college-educated more than doubles in this period and the percent of white residents increases by 74 percent, far outpacing other tracts. This influx of white residents aligns with findings from New York City, which demonstrate that incoming residents to gentrifying neighborhoods are disproportionately white (Sutton 2018). Household income remained flat in gentrifying neighborhoods while it fell in gentrifiable (-16 percent) and non-gentrifying (-12 percent) tracts. Interestingly, the share of Black residents declines in all tracts, and declines the most in gentrifiable tracts ( -45 percent). Conversely, the percent of Hispanics remains flat in gentrifying tracts, while it rises in others. These descriptive characteristics demonstrate that the measure of gentrification employed in this analysis captures many of the key elements of this process of neighborhood transition described in the literature.

Table 2 presents individual-level descriptive statistics of LA FANS respondents by wave in gentrifying, gentrifiable, and non-gentrifying tracts. Between waves 1 and 2, the health of residents in gentrifying and gentrifiable neighborhoods increased roughly equally, by nearly 7 percent. Health in non-gentrifying neighborhoods remained flat over time, however. In wave 1, residents living in gentrifying tracts had lived in a neighborhood experiencing gentrification during any point in their residential histories for an average of 3 years. By wave 2, the average for this group had risen to nearly 7 years. 
Table 2: Individual-level Means at Waves 1 and 2

\begin{tabular}{|c|c|c|c|c|c|c|c|c|c|}
\hline & \multicolumn{2}{|l|}{ Wave 1} & \multicolumn{3}{|c|}{ Wave 2} & \multicolumn{4}{|c|}{$\%$ Change Wave 1 to Wave 2} \\
\hline & Gentrifying & Gentrifiable & $\begin{array}{l}\text { Not } \\
\text { Gentrifying }\end{array}$ & Gentrifying & Gentrifiable & $\begin{array}{l}\text { Not } \\
\text { Gentrifying }\end{array}$ & Gentrifying & Gentrifiable & $\begin{array}{l}\text { Not } \\
\text { Gentrifying }\end{array}$ \\
\hline \multirow[t]{2}{*}{ Self-rated health } & 3.0 & 3.1 & 3.6 & 3.2 & 3.3 & 3.6 & 6.7 & 6.5 & 0.0 \\
\hline & $(1.1)$ & $(1.1)$ & $(1.1)$ & $(1.2)$ & $(1.1)$ & $(1.1)$ & 9.1 & 0.0 & 0.0 \\
\hline \multirow[t]{2}{*}{ Years in gentrified tract } & 3.2 & 0.8 & 0.0 & 6.9 & 1.7 & 0.3 & 115.6 & 112.5 & . \\
\hline & $(3.3)$ & $(2.2)$ & $(0.4)$ & $(3.9)$ & $(3.1)$ & $(1.1)$ & 18.2 & 40.9 & 175.0 \\
\hline \multirow[t]{2}{*}{$\%$ Hispanic } & 87.0 & 78.3 & 37.7 & 77.9 & 81.5 & 43.6 & -10.5 & 4.1 & 15.6 \\
\hline & $(33.7)$ & $(41.3)$ & $(48.5)$ & $(41.5)$ & $(38.9)$ & $(49.6)$ & 23.1 & -5.8 & 2.3 \\
\hline \multirow[t]{2}{*}{$\%$ White } & 1.7 & 10.5 & 44.0 & 5.8 & 8.5 & 38.1 & 241.2 & -19.0 & -13.4 \\
\hline & $(12.9)$ & $(30.7)$ & $(49.7)$ & $(23.3)$ & $(27.9)$ & $(48.6)$ & 80.6 & -9.1 & -2.2 \\
\hline \multirow[t]{2}{*}{$\%$ Black } & 8.4 & 9.0 & 6.1 & 13.3 & 7.8 & 6.6 & 58.3 & -13.3 & 8.2 \\
\hline & $(27.7)$ & $(28.6)$ & $(24.0)$ & $(34.0)$ & $(26.8)$ & $(24.8)$ & 22.7 & -6.3 & 3.3 \\
\hline \multirow[t]{2}{*}{$\%$ Asian } & 2.9 & 2.2 & 12.1 & 3.1 & 2.2 & 11.7 & 6.9 & 0.0 & -3.3 \\
\hline & $(16.9)$ & $(14.6)$ & $(32.7)$ & $(17.2)$ & $(14.8)$ & $(32.2)$ & 1.8 & 1.4 & -1.5 \\
\hline \multirow[t]{2}{*}{$\%$ Women } & 71.5 & 74.0 & 69.1 & 66.7 & 68.2 & 64.4 & -6.7 & -7.8 & -6.8 \\
\hline & $(45.2)$ & $(43.9)$ & $(46.2)$ & $(47.2)$ & $(46.6)$ & $(47.9)$ & 4.4 & 6.2 & 3.7 \\
\hline \multirow[t]{2}{*}{$\%$ College degree } & 5.4 & 6.2 & 40.2 & 7.7 & 6.5 & 33.9 & 42.6 & 4.8 & -15.7 \\
\hline & $(22.7)$ & $(24.1)$ & $(49.1)$ & $(26.7)$ & $(24.7)$ & $(47.3)$ & 17.6 & 2.5 & -3.7 \\
\hline \multirow[t]{2}{*}{ Income } & $27,545.1$ & $30,021.0$ & $65,874.7$ & $34,576.3$ & $35,660.7$ & $58,931.1$ & 25.5 & 18.8 & -10.5 \\
\hline & $(15,853.7)$ & $(19,856.3)$ & $(52,927.5)$ & $(20,090.5)$ & $(19,389.4)$ & $(38,738.4)$ & 26.7 & -2.4 & -26.8 \\
\hline \multirow[t]{2}{*}{ Age } & 36.7 & 37.4 & 40.6 & 37.5 & 38.3 & 39.4 & 2.2 & 2.4 & -3.0 \\
\hline & $(12.7)$ & $(12.0)$ & $(12.9)$ & $(13.9)$ & $(15.4)$ & $(15.2)$ & 9.4 & 28.3 & 17.8 \\
\hline \multirow[t]{2}{*}{ Married } & 57.7 & 54.8 & 70.4 & 40.6 & 41.2 & 52.0 & -29.6 & -24.8 & -26.1 \\
\hline & $(49.5)$ & $(49.8)$ & $(45.7)$ & $(49.2)$ & $(49.3)$ & $(50.0)$ & -0.6 & -1.0 & 9.4 \\
\hline \multirow[t]{2}{*}{$\%$ With child(ren) home } & 81.6 & 89.5 & 84.4 & 42.1 & 41.0 & 41.7 & -48.4 & -54.2 & -50.6 \\
\hline & $(38.8)$ & $(30.7)$ & $(36.3)$ & $(49.4)$ & $(49.2)$ & $(49.3)$ & 27.3 & 60.3 & 35.8 \\
\hline \multirow[t]{2}{*}{ Total moves } & 0.0 & 0.0 & 0.0 & 0.4 & 0.4 & 0.5 & . & . & . \\
\hline & $(0.1)$ & $(0.1)$ & $(0.2)$ & $(0.6)$ & $(0.6)$ & $(0.7)$ & 500.0 & 500.0 & 250.0 \\
\hline $\mathrm{N}$ & 234 & 312 & 596 & 555 & 397 & 1073 & . & . & . \\
\hline
\end{tabular}

Note: All dollar amounts are standardized to 2012. Standard deviations in parentheses. 
In a similar manner to the tract-level characteristics in Table 1, many of the trends at the individual level align well with the literature on gentrifying neighborhoods. The share of Hispanic residents in gentrifying neighborhoods declines by nearly 11 percent, while it increases by 4 percent and 16 percent in gentrifiable and non-gentrifying tracts, respectively. The percentage of white residents in tracts experiencing gentrification increases by a factor of 3 , while it declines in gentrifiable (-19 percent) and non-gentrifying tracts (-13 percent). Interestingly, the percent of Black L.A. FANS respondents increased the most in gentrifying neighborhoods (58 percent), followed by gentrifying tracts( 8 percent), and it declined in gentrifiable tracts by 13 percent. The percentage of residents with a college degree increases the most in gentrifying tracts at 43 percent, followed by gentrifiable tracts ( 5 percent). It declines by 16 percent in non-gentrifying tracts during this time period. Finally, L.A. FANS respondents in gentrifying tracts experience the greatest rise in income (26 percent), followed by gentrifiable (19 percent) and non-gentrifying neighborhoods (-11 percent). Moving is generally infrequent among all residents, as the total number of residential moves does not exceed 0.5 in all neighborhoods by wave 2 .

\subsection{Changes in Duration of Exposure to Gentrification}

Table 3 presents estimates of the extent to which the health of individuals changes as they experience gentrification for longer durations. Model 1 of Table 3 indicates that each additional year of residence in a gentrifying tract is associated with a 0.04 -point increase in health. The average length of residence in a gentrifying neighborhood for residents currently residing in a tract undergoing this form of neighborhood change is nearly 7 years by wave 2 . This means that individuals who have resided in gentrifying tracts for this length of time can expect to see more than a quarter of a point increase in self-rated health $(0.04 * 7=0.28)$. These results indicate that 
the neighborhood upgrades and increased access to neighborhood resources and amenities are associated with better health for residents. Model 2 interacts duration of gentrification with race, and the link between duration of exposure to gentrification and health does not vary across racial and ethnic groups as hypothesized. ${ }^{12}$ Results using unimputed data are similar in magnitude and direction. $^{13}$

Table 3: Changes in Duration of Gentrification, Both Waves (Individual Fixed Effects)

\begin{tabular}{|c|c|c|}
\hline VARIABLES & $\begin{array}{l}(1) \\
\text { All }\end{array}$ & $\begin{array}{l}(2) \\
\text { All }\end{array}$ \\
\hline Years $r$ lived in gentrifying tract & $\begin{array}{l}0.038^{*} \\
(0.015)\end{array}$ & $\begin{array}{l}-0.011 \\
(0.037)\end{array}$ \\
\hline \multicolumn{3}{|c|}{$\begin{array}{l}\text { Race and gentrification duration interaction (ref.= } \\
\text { Whites) }\end{array}$} \\
\hline Hispanic $\mathrm{x}$ Years in gentrified tract & & $\begin{array}{c}0.065 \\
(0.040)\end{array}$ \\
\hline Black $x$ Years in gentrified tract & & $\begin{array}{c}0.005 \\
(0.053)\end{array}$ \\
\hline Asian/other $\mathrm{x}$ Years in gentrified tract & & $\begin{array}{c}0.095 \\
(0.092)\end{array}$ \\
\hline \multicolumn{3}{|l|}{ Education (ref.=less than HS) } \\
\hline HS Grad & $\begin{array}{c}-0.349 * \\
(0.159)\end{array}$ & $\begin{array}{c}-0.349 * \\
(0.159)\end{array}$ \\
\hline Some College & $\begin{array}{c}0.357^{*} \\
(0.174)\end{array}$ & $\begin{array}{l}0.364 * \\
(0.174)\end{array}$ \\
\hline College or more & $\begin{array}{c}0.009 \\
(0.178)\end{array}$ & $\begin{array}{c}0.008 \\
(0.177)\end{array}$ \\
\hline Log Individual Income & $\begin{array}{c}0.031 \\
(0.054)\end{array}$ & $\begin{array}{c}0.024 \\
(0.054)\end{array}$ \\
\hline Age & $\begin{array}{c}-0.021^{* *} \\
(0.006)\end{array}$ & $\begin{array}{c}-0.020 * * \\
(0.006)\end{array}$ \\
\hline Unmarried (ref. $=$ married) & $\begin{array}{l}0.229 * \\
(0.100)\end{array}$ & $\begin{array}{l}0.250 * \\
(0.101)\end{array}$ \\
\hline Child(ren) live in household & $\begin{array}{c}0.114 \\
(0.066)\end{array}$ & $\begin{array}{c}0.116 \\
(0.066)\end{array}$ \\
\hline Constant & $\begin{array}{c}3.908 * * * \\
(0.696)\end{array}$ & $\begin{array}{c}3.961 * * * \\
(0.699)\end{array}$ \\
\hline
\end{tabular}


Individual Fixed Effects

Observations

Respondents
Yes

3,164

2,024
Yes

3,164

2,024

Standard errors in parentheses

$* * * \mathrm{p}<0.001, * * \mathrm{p}<0.01, * \mathrm{p}<0.05$

Figure 1 presents predicted values of self-reported health based on Model 1 of Table 3. As is indicated in Table 3, each additional year of gentrification is associated with increased selfreported health in the full sample. The predicted self-reported health for those with 1 year of exposure to gentrification is just under 3.5 on a 5-point scale. By 7 years of exposure to gentrification, the average duration for residents currently residing in a gentrifying tract by wave 2, self- reported health rises to 3.7. This within-person increase in health over time with additional years of exposure to gentrification occurs even after controlling for age, which is associated with declining health. In sum, this figure provides further support for the hypothesis that the increased neighborhood amenities and declines in certain kinds of crime associated with gentrification is associated with better health.

Because the residents of gentrifying neighborhoods become more white and earn higher incomes over time as demonstrated in Table 2, it may appear that results simply reflect the better health outcomes that these more advantaged groups have been found to experience. Table 2 demonstrates that by wave 2, residents of gentrifying neighborhoods have resided in tracts undergoing this kind of change for an average of 7 years. Moreover, residents of gentrifying tracts move about as little as residents in non-gentrifying tracts, at 0.4 and 0.5 total moves respectively by wave 2 . The relatively lengthy residence of residents in gentrifying neighborhoods, coupled with low levels of residential mobility among those in both gentrifying and non-gentrifying neighborhoods alike, provides further evidence that the observed health 
gains that accompany residence in a gentrifying neighborhood are not simply an artifact of demographic shifts in these neighborhoods.

\section{Figure 1: Duration of Gentrification and Self-reported Health (95\% Confidence Intervals)}

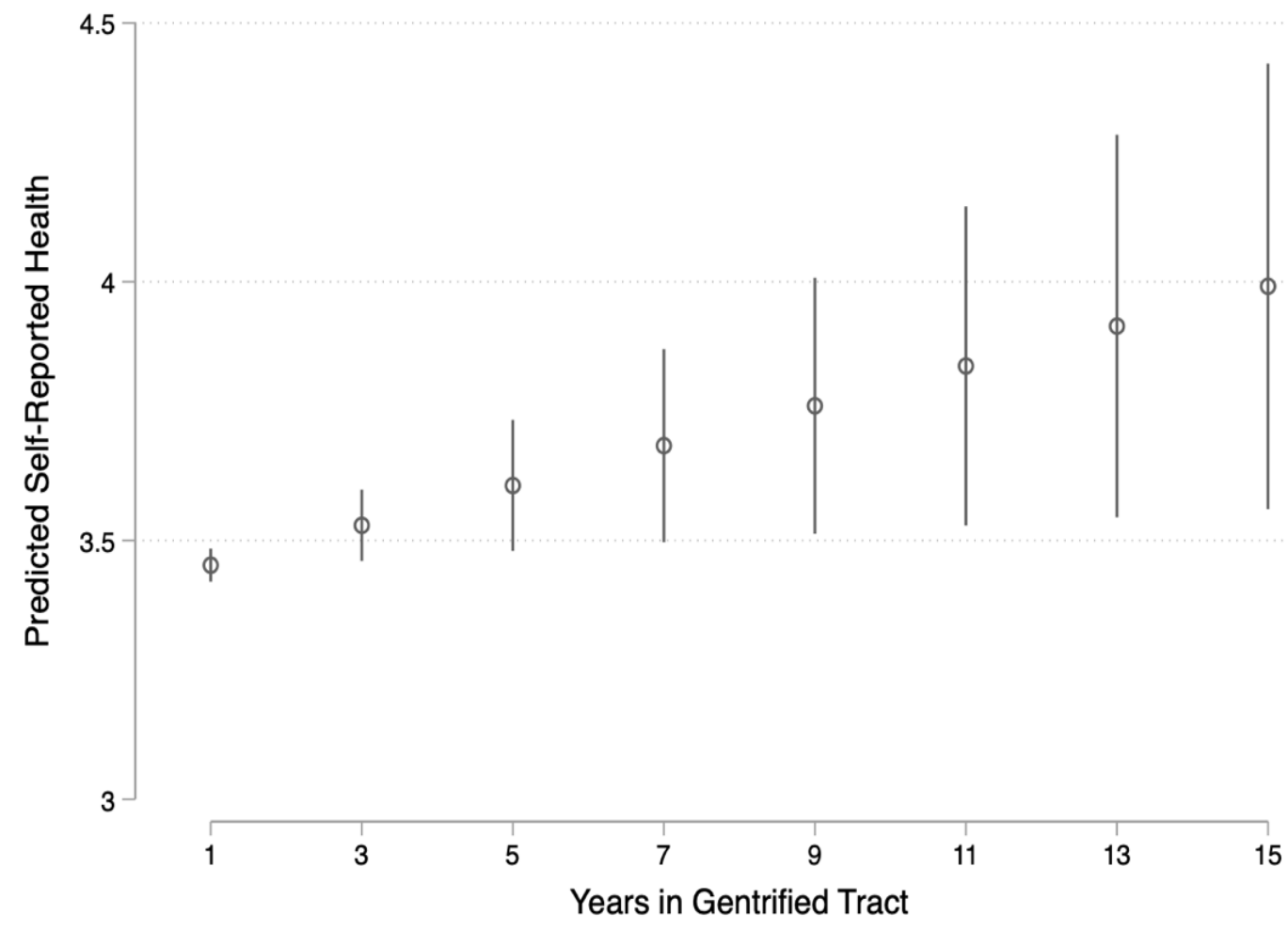

Figure plots predicted self-reported health from Table 3, Model 1, using individuallevel fixed effects and all control variables. Estimates are based on both waves of L.A.FANS and U.S. Census data from 1990 to 2010.

\section{ROBUSTNESS CHECK: NEIGHBORHOOD STABILITY AND HEALTH}

In an effort to ensure that the observed relationship between duration of exposure to gentrification and increased health is not a spurious one related to the positive effects of remaining in a neighborhood for long periods of time, I explore the relationship between duration of exposure to stable, low-SES neighborhoods and self-reported health. I use stable lowSES neighborhoods, rather than stable middle- or high-SES neighborhoods, primarily because extant research finds that residence in more affluent neighborhood is linked with greater self- 
rated health (Browning et al. 2003; Wen et al. 2003). Testing the link between remaining in a stable neighborhood and health is also preferable to analyzing the health of residents in declining tracts, largely because if the neighborhood is experiencing decline on a number of dimensions, there may also be forces at play within the neighborhood that are negatively linked to health. This would confound any observed association between remaining in a declining neighborhood and health. For these reasons, I look specifically at stable neighborhoods that are most similar to the ones that eventually gentrify. Low-SES, stable tracts are defined as those that (a) are not gentrifying, and (b) remain in the bottom 3 deciles of rent and percent of people with a college degree, or they remain in the bottom 3 deciles of income and college graduates during each year from 1990 to $2008 .^{14}$

Table 4: Duration of Low-SES Stability and Health, Both Waves (Individual Fixed Effects)

\begin{tabular}{lcc}
\hline \hline & $(1)$ & $(2)$ \\
VARIABLES & All & All \\
\hline Years lived in stable low-SES tract & -0.0234 & -0.106 \\
Race and stability duration interaction (ref.= Whites) & $(0.0342)$ & $(0.160)$ \\
Hispanic x Years in stable low-SES tract & & \\
& & 0.107 \\
Black x Years in stable low-SES tract & & $(0.164)$ \\
& & -0.0357 \\
Asian/other x Years in stable low-SES tract & & $(0.185)$ \\
& & -0.242 \\
Education (Ref=less than HS) & & $(0.652)$ \\
HS Grad & & \\
Some college & & $-0.374 *$ \\
College or more & $-0.371^{*}$ & $(0.160)$ \\
Log individual Income & $0.346^{*}$ & $0.344^{*}$ \\
& $(0.174)$ & $(0.174)$ \\
& 0.00639 & -0.000215
\end{tabular}




\begin{tabular}{lcc} 
& $(0.0540)$ & $(0.0539)$ \\
Age & $-0.0155^{*}$ & $-0.0156^{*}$ \\
Unmarried (ref.=married) & $(0.00618)$ & $(0.00621)$ \\
& $0.245^{*}$ & $0.245^{*}$ \\
Child(ren) live in household & $(0.100)$ & $(0.102)$ \\
& 0.107 & 0.110 \\
Constant & $(0.0666)$ & $(0.0668)$ \\
& $3.677^{* * *}$ & $3.691 * * *$ \\
Individual Fixed Effects & $(0.692)$ & $(0.693)$ \\
Observations & Yes & Yes \\
Respondents & 3,164 & 3,164 \\
\hline Standard errors in parentheses & 2,024 & 2,024 \\
$* * * \mathrm{p}<0.001, * * \mathrm{p}<0.01, * \mathrm{p}<0.05$ & & \\
\hline \hline
\end{tabular}

Table 4 presents estimates of the relationship between duration of residence in a stably low-income census tract. Results indicate that the link between duration of residence in a lowSES, stable neighborhood and self-reported health is not statistically significant. This finding provides further support for the robustness of the positive relationship between duration of exposure to gentrification and health described in the primary analysis.

\section{DISCUSSION AND CONCLUSIONS}

Gentrification is often presented as a solution to urban problems ranging from depleted tax bases to street crime. Although gentrification has been promoted as a remedy to many of the issues that ail cities, several questions remain concerning how this process of neighborhood change is related to the health of residents. In this analysis, I have asked two questions. First, how is duration of exposure to gentrification linked to the self-reported health of those who remain in the neighborhood? Second, how does this relationship vary for members of different racial and ethnic groups? Results indicate that living in a gentrifying neighborhood for longer percids of time is associated with better self-reported health. This relationship does not vary by 
race or ethnicity. These results support the hypothesis that a longer duration of residence in a gentrifying neighborhood is associated with greater health as a result of repairs to the built environment, lower rates of homicide, and greater access to neighborhood amenities.

These findings broadly align with extant literature, which finds either a positive association between gentrification and health (Gibbons and Barton 2016) or the absence of a negative relationship (Mary Huynh and Maroko 2014; Izenberg et al. 2018) in the full sample. Because the findings of the present paper are similar to the small but growing literature investigating the relationship between gentrification and health, this suggests that despite the distinct nature of Los Angeles in terms of housing stock and density, the results presented here can be generalized to other major east coast cities with caution.

This study is not without limitations. First, the number of people who move out of gentrifying neighborhoods is small in the L.A. FANS, making it difficult to explore the relationship between gentrification and health within this subsample of movers. Second, this analysis relies on data from Los Angeles County. While this setting is a useful case for examining gentrification due to the rapid changes in L.A. neighborhoods, the diversity of residents, and its ongoing housing shortage - future research should explore other localities, or perhaps employ a large national sample, to better understand how these dynamics play out more broadly. Finally, although this analysis controls for fixed, unobserved characteristics of individuals over time, it cannot control for time-varying individual-level variables that may be associated with both health and gentrification. Results are therefore correlational.

This work makes important empirical and theoretical contributions to the literature concerned with Urban Sociology. First, this study makes an empirical contribution to the neighborhood effects literature. Urban scholars have long argued that the research on 
neighborhood effects should take seriously how the demographic composition of individuals in a neighborhood, rather than the broader residential context, may contribute to individual-level outcomes for residents (Sampson and Sharkey 2008). The present study addresses the issue of neighborhood selection by deploying duration of exposure to gentrification, rather than contemporaneous residence in a transitioning neighborhood alone. Moreover, the use of longitudinal data at the individual and tract level allows for unchanging, unobserved characteristics of individuals to be held constant. Though results do not fully account for selection into neighborhoods, this approach is an improvement over cross-sectional neighborhood analyses.

Second, these findings have important theoretical implications, as they provide further insight into Lefebvre's (1991) concept of "social space." Gentrification provides an example of not only the role of space in reproducing the social hierarchy, but also how a reversal of spatial power relations from the suburbs to central cities can benefit the health of longtime, more disadvantaged residents. The increase in power concentrated in gentrifying neighborhoods manifests in the form of upgrades to the built environment, increased neighborhood investment, an influx of services and healthier food stores, and declines in certain kinds of violent crime (Anguelovski 2015; Ellen et al. 2001; Papachristos et al. 2011). Although longtime residents of gentrifying neighborhoods are more disadvantaged, their health benefits from the power that is increasingly concentrated in their neighborhoods as they gentrify. Conceptualizing gentrification as an example of shifting spatial power relations gives rise to questions that should be taken up in future research. For instance, as power shifts away from a well-resourced neighborhood and it experiences decline, how does this impact the health of long-time residents? In addition, future 
research should delve more deeply into the lived experiences of long-time residents, as both the boundaries and composition of the neighborhood changes over time.

Although duration of exposure to gentrification is positively linked to the health of residents who are able to stay in these neighborhoods, this does not mean that the same is true of movers. The sample of residents who move out of gentrifying neighborhoods in this analysis is too small to explore using a regression framework. Future research should take up this issue and investigate the relationship between displacement from a gentrifying neighborhood and health.

The results of this study are not an endorsement of the use of gentrification as a public health intervention. Gentrification is also associated with social, physical, and institutional displacement, as well as heightened class-based and racial tensions (Anderson 1997:199; Freeman 2006; Gibbons et al. 2019; Hicken et al. 2018; Logan and Molotch 1987; Sullivan and Shaw 2011; Zukin 2011). Instead, findings reiterate the importance of neighborhood investments for the health and well-being of their residents. The results presented here suggest that if longtime residents are to reap the health benefits of the neighborhood improvements that accompany gentrification, efforts must be made to allow these residents to remain in their neighborhoods as they undergo change. Rather than promoting pro-gentrification policies, legislators should work with communities to make the kinds of investments and attract the kinds of businesses that community members want, while working to prevent the social and physical displacement of the most disadvantaged residents. 


\section{Acknowledgements}

I am eternally grateful to Margot Jackson, Jackelyn Hwang, John Logan, Josh Pacewicz, Amanda Ball, Danielle Falzon, Laura Garbes, Ieva Zumbyte, and participants at research seminars in the Department of Sociology and the Population Studies and Training Center at Brown University for providing crucial feedback on numerous drafts. I gratefully acknowledge support from the Population Studies and Training Center at Brown University through the generosity of the Eunice Kennedy Shriver National Institute of Child Health and Human Development (P2C HD041020, T32 HD007338, and T32 HD00733830). I am also grateful to the Health Policy Research Scholars Program through the Robert Wood Johnson Foundation for funding this research. 


\section{REFERENCES}

Allison, Paul David. 2002. Missing Data. Thousand Oaks, Calif: Sage Publications.

Allison, Paul David. 2009. Fixed Effects Regression Models. Los Angeles: SAGE.

Anderson, Elijah. 1997. Streetwise: Race, Class, and Change in an Urban Community. Chicago: Univ. of Chicago Press.

Anguelovski, Isabelle. 2015. "Healthy Food Stores, Greenlining and Food Gentrification: Contesting New Forms of Privilege, Displacement and Locally Unwanted Land Uses in Racially Mixed Neighborhoods." International Journal of Urban and Regional Research 39(6):1209-30. doi: 10.1111/1468-2427.12299.

Barragan, Bianca. 2015. “58.5 Percent of Los Angeles Renters Can’t Afford Their Rent.” Curbed $L A$, October 12.

Boardman, Jason D., Brian Karl Finch, Christopher G. Ellison, David R. Williams, and James S. Jackson. 2001. "Neighborhood Disadvantage, Stress, and Drug Use among Adults." Journal of Health and Social Behavior 42(2):151-65. doi: 10.2307/3090175.

Boggess, Lyndsay N., and John R. Hipp. 2016. "The Spatial Dimensions of Gentrification and the Consequences for Neighborhood Crime." Justice Quarterly 33(4):584-613. doi: 10.1080/07418825.2014.943799.

Browning, Christopher R., and Kathleen A. Cagney. 2002. "Neighborhood Structural Disadvantage, Collective Efficacy, and Self-Rated Physical Health in an Urban Setting." Journal of Health and Social Behavior 43(4):383-99. doi: 10.2307/3090233.

Browning, Christopher R., Kathleen A. Cagney, and Ming Wen. 2003. "Explaining Variation in Health Status across Space and Time: Implications for Racial and Ethnic Disparities in Self-Rated Health." Social Science \& Medicine 57(7):1221-35. doi: 10.1016/S02779536(02)00502-6.

Brown-Saracino, Japonica. 2017. "Explicating Divided Approaches to Gentrification and Growing Income Inequality." Annual Review of Sociology 43(1):515-39. doi: 10.1146/annurev-soc060116-053427.

Caplan, Gerald. 1974. Support Systems and Community Mental Health: Lectures on Concept Development. New York: Behavioral Publications.

Carlson, H. Jacob. 2020. "Measuring Displacement: Assessing Proxies for Involuntary Residential Mobility." City \& Community. doi: 10.1111/cico.12482.

Cassel, John. 1976. "The Contribution of the Social Environment to Host Resistance: The Fourth Wade Hampton Frost Lecture." American Journal of Epidemiology 104(2):107-23. 
Casselman, Ben. 2018. "Promising Billions to Amazon: Is It a Good Deal for Cities?" The New York Times, November 9.

Chiland, Elijah. 2018. "Single-Family Homes Cover Almost Half of Los Angeles.” Curbed LA. Retrieved January 31, 2020 (https://la.curbed.com/2018/9/10/17827982/single-familyhouses-los-angeles-zoning-rules-explained).

Clarke, Philippa, Jeffrey Morenoff, Michelle Debbink, Ezra Golberstein, Michael R. Elliott, and Paula M. Lantz. 2013. "Cumulative Exposure to Neighborhood Context: Consequences for Health Transitions Over the Adult Life Course." Research on Aging 36(1):115-42. doi: $10.1177 / 0164027512470702$.

Cohen, Sheldon, and Garth McKay. 1984. "Social Support, Stress and the Buffering Hypothesis: A Theoretical Analysis." in Social psychological aspects of health, Handbook of psychology and health, edited by A. Baum, S. E. Taylor, and J. E. Singer. Hillsdale, N.J: L. Erlbaum Associates.

Colby, Sandra L., and Jennifer M. Ortman. 2015. Projections of the Size and Composition of the U.S. Population: 2014 to 2060. P25-1143. Washington, D.C.: U.S. Census Bureau.

Connolly, Nathan D. B. 2014. A World More Concrete: Real Estate and the Remaking of Jim Crow South Florida. Chicago ; London: The University of Chicago Press.

Crowder, Kyle, and Scott J. South. 2008. "Spatial Dynamics of White Flight: The Effects of Local and Extralocal Racial Conditions on Neighborhood Out-Migration." American Sociological Review 73(5):792-812.

Currier, Erin, Clinton Key, Joanna Biernacka-Lievestro, Walter Lake, Sheida Elmi, Sowmaya Kypa, and Abigail Lantz. 2018. American Families Face a Growing Rent Burden. Philadelphia, PA: Pew Charitable Trusts.

Davis, Mike. 2006. City of Quartz: Excavating the Future in Los Angeles. New ed. London; New York: Verso.

Desmond, Matthew, Carl Gershenson, and Barbara Kiviat. 2015. "Forced Relocation and Residential Instability among Urban Renters.” Social Service Review 89(2):227-62. doi: 10.1086/681091.

Ding, Lei, Jackelyn Hwang, and Eileen Divringi. 2016. "Gentrification and Residential Mobility in Philadelphia." Regional Science and Urban Economics 61:38-51. doi: 10.1016/j.regsciurbeco.2016.09.004.

Du Bois, William E. B. 1899. The Philadelphia Negro: A Social Study. Philadelphia: University of Pennsylvania Press.

Ellen, Ingrid Gould, Tod Mijanovich, and Keri-Nicole Dillman. 2001. "Neighborhood Effects on Health: Exploring the Links and Assessing the Evidence." Journal of Urban Affairs 23(3 \& 4):391-408. 
Ellen, Ingrid Gould, and Katherine O'Regan. 2008. "Reversal of Fortunes? Lower-Income Urban Neighbourhoods in the US in the 1990s." Urban Studies 45(4):845-69. doi: $10.1177 / 0042098007088471$.

Ellen, Ingrid Gould, and Katherine M. O'Regan. 2011. "How Low Income Neighborhoods Change: Entry, Exit, and Enhancement." Regional Science and Urban Economics 41(2):89-97. doi: https://doi.org/10.1016/j.regsciurbeco.2010.12.005.

Ferraro, Kenneth F., and Melissa M. Farmer. 1999. "Utility of Health Data from Social Surveys: Is There a Gold Standard for Measuring Morbidity?" American Sociological Review 64(2):303-15. doi: 10.2307/2657534.

Frank, Reanne, and Eileen Bjornstrom. 2011. "A Tale of Two Cities: Residential Context and Risky Behavior among Adolescents in Los Angeles and Chicago." Health \& Place 17(1):67-77. doi: 10.1016/j.healthplace.2010.08.017.

Freeman, Lance. 2005. "Displacement or Succession?: Residential Mobility in Gentrifying Neighborhoods." Urban Affairs Review 40(4):463-91. doi: 10.1177/1078087404273341.

Freeman, Lance. 2006. There Goes the 'hood: Views of Gentrification from the Ground Up. Philadelphia, Pa: Temple University Press.

Freeman, Lance, and Frank Braconi. 2004. "Gentrification and Displacement New York City in the 1990s." Journal of the American Planning Association 70(1):39-52. doi: $10.1080 / 01944360408976337$.

Fullilove, Mindy Thompson. 2016. Root Shock: How Tearing Up City Neighborhoods Hurts America, and What We Can Do about It. New York: One World/Ballantine Books.

Gibbons, Joseph. 2019. "The Effect of Segregated Cities on Ethnoracial Minority Healthcare System Distrust." City \& Community 18(1):321-43. doi: 10.1111/cico.12370.

Gibbons, Joseph, and Michael S. Barton. 2016. "The Association of Minority Self-Rated Health with Black versus White Gentrification." Journal of Urban Health 93(6):909-22. doi: 10.1007/s11524-016-0087-0.

Gibbons, Joseph, Michael S. Barton, and Timothy T. Reling. 2019. "Do Gentrifying Neighbourhoods Have Less Community? Evidence from Philadelphia." Urban Studies 004209801982933. doi: 10.1177/0042098019829331.

Glass, Ruth. 1964. "Introduction: Aspects of Change." Pp. xiii-xlii in London: Aspects of Change, edited by Centre for Urban Studies. London: MacKibbon and Kee.

Hammel, Daniel J., and Elvin K. Wyly. 1996. "A Model for Identifying Gentrifying Areas with Census Data.” Urban Geography 17(3):248-68. doi: 10.2747/0272-3638.17.3.248. 
Hicken, Margaret T., Hedwig Lee, and Anna K. Hing. 2018. "The Weight of Racism: Vigilance and Racial Inequalities in Weight-Related Measures." Social Science \& Medicine 199:157-66. doi: 10.1016/j.socscimed.2017.03.058.

House, James S., Karl R. Landis, and Debra Umberson. 1988. "Social Relationships and Health." Science 241(4865):540-45.

Huynh, Mary, and Andrew R. Maroko. 2014. "Gentrification and Preterm Birth in New York City, 2008-2010." Journal of Urban Health 91(1):211-20. doi: 10.1007/s11524-013-9823-x.

Hwang, Jackelyn. 2016. "The Social Construction of a Gentrifying Neighborhood: Reifying and Redefining Identity and Boundaries in Inequality." Urban Affairs Review 52(1):98-128. doi: $10.1177 / 1078087415570643$.

Hwang, Jackelyn, and Robert J. Sampson. 2014. "Divergent Pathways of Gentrification: Racial Inequality and the Social Order of Renewal in Chicago Neighborhoods." American Sociological Review 79(4):726-51. doi: 10.1177/0003122414535774.

Hyra, Derek, Dominic Moulden, Carley Weted, and Mindy Fullilove. 2019. "A Method for Making the Just City: Housing, Gentrification, and Health." Housing Policy Debate 29(3):421-31. doi: 10.1080/10511482.2018.1529695.

Hyra, Derek S. 2017. Race, Class, and Politics in the Cappuccino City. Chicago ; London: The University of Chicago Press.

Idler, Ellen L., and Yael Benyamini. 1997. "Self-Rated Health and Mortality: A Review of Twenty-Seven Community Studies." Journal of Health and Social Behavior 38(1):21-37. doi: $10.2307 / 2955359$.

Izenberg, Jacob M., Mahasin S. Mujahid, and Irene H. Yen. 2018. "Health in Changing Neighborhoods: A Study of the Relationship between Gentrification and Self-Rated Health in the State of California." Health \& Place 52:188-95. doi: 10.1016/j.healthplace.2018.06.002.

Jackson, Margot I., and Robert D. Mare. 2007. "Cross-Sectional and Longitudinal Measurements of Neighborhood Experience and Their Effects on Children." Social Science Research 36(2):590-610. doi: 10.1016/j.ssresearch.2007.02.002.

Kawachi, Ichirō, and Lisa F. Berkman, eds. 2003. Neighborhoods and Health. Oxford; New York: Oxford University Press.

Khouri, Andrew. 2018. "Sky-High Rents and Home Prices Are Making It Hard for Southern California Businesses to Attract Workers." Los Angeles Times, February 28.

Klinenberg, Eric. 2003. Heat Wave: A Social Autopsy of Disaster in Chicago. Chicago London: Univ. of Chicago Press. 
Korver-Glenn, Elizabeth. 2018. "Compounding Inequalities: How Racial Stereotypes and Discrimination Accumulate across the Stages of Housing Exchange." American Sociological Review 83(4):627-56. doi: 10.1177/0003122418781774.

Krantz, David S., and Melissa K. McCeney. 2002. "Effects of Psychological and Social Factors on Organic Disease: A Critical Assessment of Research on Coronary Heart Disease." Annual Review of Psychology 53(1):341-69. doi: 10.1146/annurev.psych.53.100901.135208.

Lacy, Karyn. 2016. "The New Sociology of Suburbs: A Research Agenda for Analysis of Emerging Trends." Annual Review of Sociology 42(1):369-84. doi: 10.1146/annurev-soc071312-145657.

Lefebvre, Henri. 1991. The Production of Space. Malden, Massachusetts: Blackwell.

Logan, John R., and Harvey Luskin Molotch. 1987. Urban Fortunes: The Political Economy of Place. Berkeley, Calif.: Univ. of California Pr.

Logan, John R., Zengwang Xu, and Brian J. Stults. 2014. "Interpolating U.S. Decennial Census Tract Data from as Early as 1970 to 2010: A Longitudinal Tract Database." The Professional Geographer 66(3):412-20. doi: 10.1080/00330124.2014.905156.

Martin, Isaac William, and Kevin Beck. 2016. "Gentrification, Property Tax Limitation, and Displacement.” Urban Affairs Review 54(1):33-73. doi: 10.1177/1078087416666959.

Massey, Douglas S., and Nancy A. Denton. 1993. American Apartheid: Segregation and the Making of the Underclass. 10th ed. Cambridge, Mass.: Harvard Univ. Press.

Morenoff, Jeffrey D. 2003. "Neighborhood Mechanisms and the Spatial Dynamics of Birth Weight." American Journal of Sociology 108(5):976-1017. doi: 10.1086/374405.

Newman, Kathe, and Elvin Wyly. 2006. "The Right to Stay Put, Revisited: Gentrification and Resistance to Displacement in New York City." Urban Studies 43(1):23-57. doi: 10.1080/00420980500388710.

Pager, Devah, and Hana Shepherd. 2008. "The Sociology of Discrimination: Racial Discrimination in Employment, Housing, Credit, and Consumer Markets." Annual Review of Sociology 34(1):181-209. doi: 10.1146/annurev.soc.33.040406.131740.

Papachristos, Andrew V., Chris M. Smith, Mary L. Scherer, and Melissa A. Fugiero. 2011. "More Coffee, Less Crime? The Relationship between Gentrification and Neighborhood Crime Rates in Chicago, 1991 to 2005." City \& Community 10(3):215-40. doi: 10.1111/j.15406040.2011.01371.x.

Park, Robert E., Earnest W. Burgess, Robert McKenzie, and Louis Wirth. 1925. The City. 1st ed. Chicago, IL: University of Chicago Press. 
Pattillo, Mary E. 2008. Black on the Block: The Politics of Race and Class in the City. Chicago: University of Chicago Press.

Rosenblatt, Peter, and Jennifer E. Cossyleon. 2018. "Pushing the Boundaries: Searching for Housing in the Most Segregated Metropolis in America: PUSHING THE BOUNDARIES.” City \& Community 17(1):87-108. doi: 10.1111/cico.12288.

Sampson, Robert J. 2012. Great American City: Chicago and the Enduring Neighborhood Effect. Chicago, Ill.: Univ. of Chicago Press.

Sampson, Robert J., and Patrick Sharkey. 2008. "Neighborhood Selection and the Social Reproduction of Concentrated Racial Inequality." Demography 45(1):1-29. doi: 10.1353/dem.2008.0012.

Sampson, Robert J., Patrick Sharkey, and S. W. Raudenbush. 2008. "Durable Effects of Concentrated Disadvantage on Verbal Ability among African-American Children." Proceedings of the National Academy of Sciences 105(3):845-52. doi: 10.1073/pnas.0710189104.

Sampson, Robert J., and Alix S. Winter. 2016. "The Racial Ecology of Lead Poisoning." Du Bois Review: Social Science Research on Race 13(02):261-83. doi: 10.1017/S1742058X16000151.

Sastry, Narayan, Bonnie Ghosh-Dastidar, John Adams, and Anne R. Pebley. 2006. "The Design of a Multilevel Survey of Children, Families, and Communities: The Los Angeles Family and Neighborhood Survey." Social Science Research 35(4):1000-1024. doi: 10.1016/j.ssresearch.2005.08.002.

Sharkey, Patrick. 2013. Stuck in Place: Urban Neighborhoods and the End of Progress toward Racial Equality. Chicago: The University of Chicago Press.

Sharkey, Patrick, and Felix Elwert. 2011. "The Legacy of Disadvantage: Multigenerational Neighborhood Effects on Cognitive Ability.” American Journal of Sociology 116(6):193481. doi: 10.1086/660009.

Sharkey, Patrick, and Jacob W. Faber. 2014. "Where, When, Why, and For Whom Do Residential Contexts Matter? Moving Away from the Dichotomous Understanding of Neighborhood Effects." Annual Review of Sociology 40(1):559-79. doi: 10.1146/annurev-soc-071913043350.

Smith, Neil. 1996. The New Urban Frontier: Gentrification and the Revanchist City. London; New York: Routledge.

Smith, Neil. 2002. "New Globalism, New Urbanism: Gentrification as Global Urban Strategy." Antipode 34(3):427-50. doi: 10.1111/1467-8330.00249. 
Sullivan, Daniel M., and Samuel C. Shaw. 2011. "Retail Gentrification and Race: The Case of Alberta Street in Portland, Oregon." Urban Affairs Review 47(3):413-32. doi: $10.1177 / 1078087410393472$.

Sutton, Stacey. 2018. "Gentrification and the Increasing Significance of Racial Transition in New York City 1970-2010." Urban Affairs Review 1078087418771224. doi: $10.1177 / 1078087418771224$.

Timberlake, Jeffrey M., and Elaina Johns-Wolfe. 2016. "Neighborhood Ethnoracial Composition and Gentrification in Chicago and New York, 1980 to 2010." Urban Affairs Review 53(2):236-72. doi: 10.1177/1078087416636483.

U.S. Census Bureau. 2018. "U.S. Census Bureau QuickFacts: Los Angeles County, California." $\begin{array}{llll}\text { U.S. Census Bureau. Retrieved July } & 2019\end{array}$ (https://www.census.gov/quickfacts/fact/table/losangelescountycalifornia\#).

Warner, Cody. 2016. "The Effect of Incarceration on Residential Mobility between Poor and Nonpoor Neighborhoods.” City \& Community 15(4):423-43. doi: 10.1111/cico.12207.

Wen, Ming, Christopher R. Browning, and Kathleen A. Cagney. 2003. "Poverty, Affluence, and Income Inequality: Neighborhood Economic Structure and Its Implications for Health." Social Science \& Medicine 57(5):843-60. doi: 10.1016/S0277-9536(02)00457-4.

Wheaton, Blair, and Philippa Clarke. 2003. "Space Meets Time: Integrating Temporal and Contextual Influences on Mental Health in Early Adulthood." American Sociological Review 68(5):680-706. doi: 10.2307/1519758.

White, Ian R., Patrick Royston, and Angela M. Wood. 2011. "Multiple Imputation Using Chained Equations: Issues and Guidance for Practice.” Statistics in Medicine 30(4):377-99. doi: 10.1002/sim.4067.

White, Michael J. 1987. American Neighborhoods and Residential Differentiation. New York: Russell Sage Foundation for the National Committee for Research on the 1980 Census.

Wilson, William Julius. 1987. The Truly Disadvantaged: The Inner City, The Underclass, and Public Policy. Chicago: Univ. of Chicago Press.

Wingfield, Nick. 2018. “One Goal of Amazon's HQ2: Learn the Lessons of Seattle.” The New York Times, April 29.

Wodtke, G. T., D. J. Harding, and F. Elwert. 2011. "Neighborhood Effects in Temporal Perspective: The Impact of Long-Term Exposure to Concentrated Disadvantage on High School Graduation." American Journal of Sociology 76(5):713-36. doi: $10.1177 / 0003122411420816$.

Woetzel, Jonathan, Tim Ward, Shannon Peloquin, Steve Kling, and Sucheta Arora. 2019. Affordable Housing in Los Angeles: Delivering More--and Doing It Faster. Los Angeles: McKinsey Global Institute. 
Wyly, Elvin K., and Daniel J. Hammel. 2004. "Gentrification, Segregation, and Discrimination in the American Urban System." Environment and Planning A: Economy and Space 36(7):1215-41. doi: 10.1068/a3610.

Zukin, Sharon. 2011. Naked City: The Death and Life of Authentic Urban Places. Oxford: Oxford University Press. 
APPENDIX A

Within- \& Between-Panel Standard Deviations of Covariates

\begin{tabular}{lccl}
\hline & Mean & $\begin{array}{l}\text { Within } \\
\text { Std. Dev. }\end{array}$ & $\begin{array}{l}\text { Between } \\
\text { Std. Dev. }\end{array}$ \\
\hline Self-rated health & 3.4 & 0.5 & 1.0 \\
Years in gentrified tract & 1.7 & 1.3 & 2.9 \\
Hispanic & 60.1 & 0.0 & 48.9 \\
White & 24.3 & 0.0 & 42.3 \\
Black & 8.1 & 0.0 & 28.2 \\
Asian & 7.5 & 0.0 & 26.3 \\
Women & 67.7 & 0.0 & 47.5 \\
College degree & 22.1 & 10.8 & 39.3 \\
Income & 47864.9 & 8504.9 & 35000.2 \\
Age & 38.8 & 2.9 & 14.1 \\
Married & 52.7 & 15.1 & 48.1 \\
Child(ren) in home & 57.3 & 24.8 & 44.9 \\
Total moves & 0.3 & 0.3 & 0.5 \\
\hline \hline
\end{tabular}

Note: All dollar amounts are standardized to 2012. 
APPENDIX B

Mean Descriptive Statistics by Race (Pooled Waves)

\begin{tabular}{|c|c|c|c|c|}
\hline Hispanic & Gentrifying & Gentrifiable & $\begin{array}{l}\text { Not } \\
\text { Gentrifying }\end{array}$ & Total \\
\hline Health & $\begin{array}{c}3.2 \\
(1.1)\end{array}$ & $\begin{array}{c}3.3 \\
(1.0)\end{array}$ & $\begin{array}{c}3.4 \\
(1.0)\end{array}$ & $\begin{array}{c}3.3 \\
(1.0)\end{array}$ \\
\hline Years in gentrified tract & $\begin{array}{l}5.2 \\
(3.9)\end{array}$ & $\begin{array}{l}1.7 \\
(2.8)\end{array}$ & $\begin{array}{c}0.3 \\
(1.1)\end{array}$ & $\begin{array}{l}2.2 \\
(3.4)\end{array}$ \\
\hline Hispanic & $\begin{array}{l}100.0 \\
(0.0)\end{array}$ & $\begin{array}{l}100.0 \\
(0.0)\end{array}$ & $\begin{array}{l}100.0 \\
(0.0)\end{array}$ & $\begin{array}{l}100.0 \\
(0.0)\end{array}$ \\
\hline White & $\begin{array}{l}0.0 \\
(0.0)\end{array}$ & $\begin{array}{c}0.0 \\
(0.0)\end{array}$ & $\begin{array}{c}0.0 \\
(0.0)\end{array}$ & $\begin{array}{c}0.0 \\
(0.0)\end{array}$ \\
\hline Black & $\begin{array}{l}0.0 \\
(0.0)\end{array}$ & $\begin{array}{l}0.0 \\
(0.0)\end{array}$ & $\begin{array}{l}0.0 \\
(0.0)\end{array}$ & $\begin{array}{l}0.0 \\
(0.0)\end{array}$ \\
\hline Asian & $\begin{array}{l}0.0 \\
(0.0)\end{array}$ & $\begin{array}{l}0.0 \\
(0.0)\end{array}$ & $\begin{array}{l}0.0 \\
(0.0)\end{array}$ & $\begin{array}{l}0.0 \\
(0.0)\end{array}$ \\
\hline Women & $\begin{array}{l}69.6 \\
(46.0)\end{array}$ & $\begin{array}{l}68.6 \\
(46.4)\end{array}$ & $\begin{array}{l}66.0 \\
(47.4)\end{array}$ & $\begin{array}{l}67.8 \\
(46.7)\end{array}$ \\
\hline College degree & $\begin{array}{l}4.6 \\
(21.1)\end{array}$ & $\begin{array}{l}5.2 \\
(22.3)\end{array}$ & $\begin{array}{l}10.5 \\
(30.7)\end{array}$ & $\begin{array}{l}7.0 \\
(25.6)\end{array}$ \\
\hline Income & $\begin{array}{l}29323.5 \\
(15152.6)\end{array}$ & $\begin{array}{l}31249.2 \\
(16196.3)\end{array}$ & $\begin{array}{l}39785.6 \\
(21640.6)\end{array}$ & $\begin{array}{l}34022.2 \\
(18831.7)\end{array}$ \\
\hline Age & $\begin{array}{l}33.1 \\
(14.0)\end{array}$ & $\begin{array}{l}31.6 \\
(14.0)\end{array}$ & $\begin{array}{l}32.5 \\
(14.2)\end{array}$ & $\begin{array}{l}31.4 \\
(14.6)\end{array}$ \\
\hline Married & $\begin{array}{l}47.6 \\
(50.0)\end{array}$ & $\begin{array}{l}52.5 \\
(50.0)\end{array}$ & $\begin{array}{l}51.4 \\
(50.0)\end{array}$ & $\begin{array}{l}50.5 \\
(50.0)\end{array}$ \\
\hline Child(ren) in home & $\begin{array}{l}59.1 \\
(49.2)\end{array}$ & $\begin{array}{l}70.1 \\
(45.8)\end{array}$ & $\begin{array}{l}59.6 \\
(49.1)\end{array}$ & $\begin{array}{l}62.8 \\
(48.4)\end{array}$ \\
\hline Total moves & $\begin{array}{c}0.2 \\
(0.5)\end{array}$ & $\begin{array}{c}0.2 \\
(0.5)\end{array}$ & $\begin{array}{l}0.3 \\
(0.6)\end{array}$ & $\begin{array}{l}0.3 \\
(0.5)\end{array}$ \\
\hline Rent & $\begin{array}{l}1000.7 \\
(393.6)\end{array}$ & $\begin{array}{l}921.8 \\
(339.2)\end{array}$ & $\begin{array}{l}2314.9 \\
(1322.9)\end{array}$ & $\begin{array}{l}1223.6 \\
(863.4)\end{array}$ \\
\hline Home Value & $\begin{array}{l}325733.2 \\
(114322.6)\end{array}$ & $\begin{array}{l}263200.6 \\
(87309.2)\end{array}$ & $\begin{array}{l}670282.8 \\
(431548.6)\end{array}$ & $\begin{array}{l}375505.8 \\
(270507.9)\end{array}$ \\
\hline Hhld. Income & $\begin{array}{l}47200.6 \\
(17409.9)\end{array}$ & $\begin{array}{l}47511.3 \\
(17452.1)\end{array}$ & $\begin{array}{l}139031.3 \\
(86462.9)\end{array}$ & $\begin{array}{l}84458.4 \\
(72318.7)\end{array}$ \\
\hline$\%$ College & $\begin{array}{l}7.6 \\
(5.1)\end{array}$ & $\begin{array}{l}6.8 \\
(5.0)\end{array}$ & $\begin{array}{l}17.1 \\
(12.7)\end{array}$ & $\begin{array}{l}26.3 \\
(25.1)\end{array}$ \\
\hline
\end{tabular}




\begin{tabular}{lllll} 
\% White & 6.0 & 7.9 & 20.9 & 19.3 \\
& $(7.0)$ & $(8.9)$ & $(19.1)$ & $(17.8)$ \\
\% Black & 10.0 & 11.1 & 7.0 & 14.9 \\
& $(11.1)$ & $(13.5)$ & $(10.2)$ & $(14.1)$ \\
\% Hispanic & 78.5 & 75.9 & 58.1 & 52.4 \\
& $(12.4)$ & $(14.6)$ & $(25.3)$ & $(32.9)$ \\
\% Asian & 5.2 & 4.8 & 13.4 & 16.3 \\
& $(5.9)$ & $(6.3)$ & $(12.8)$ & $(15.9)$ \\
$\mathrm{N}$ & 356 & 325 & 480 & 1161 \\
\hline
\end{tabular}

\section{White}

\begin{tabular}{|c|c|c|c|c|}
\hline & Gentrifying & Gentrifiable & $\begin{array}{l}\text { Not } \\
\text { Gentrifying }\end{array}$ & Total \\
\hline \multirow[t]{2}{*}{ Health } & 2.9 & 3.4 & 3.8 & 3.8 \\
\hline & $(1.0)$ & $(1.1)$ & $(1.0)$ & $(1.0)$ \\
\hline \multirow[t]{2}{*}{ Years in gentrified tract } & 4.0 & 0.1 & 0.0 & 0.2 \\
\hline & $(2.4)$ & $(0.5)$ & $(0.2)$ & $(1.0)$ \\
\hline \multirow[t]{2}{*}{ Hispanic } & 0.0 & 0.0 & 0.0 & 0.0 \\
\hline & $(0.0)$ & $(0.0)$ & $(0.0)$ & $(0.0)$ \\
\hline \multirow[t]{2}{*}{ White } & 100.0 & 100.0 & 100.0 & 100.0 \\
\hline & $(0.0)$ & $(0.0)$ & $(0.0)$ & $(0.0)$ \\
\hline \multirow[t]{2}{*}{ Black } & 0.0 & 0.0 & 0.0 & 0.0 \\
\hline & $(0.0)$ & $(0.0)$ & $(0.0)$ & $(0.0)$ \\
\hline \multirow[t]{2}{*}{ Asian } & 0.0 & 0.0 & 0.0 & 0.0 \\
\hline & $(0.0)$ & $(0.0)$ & $(0.0)$ & $(0.0)$ \\
\hline \multirow[t]{2}{*}{ Women } & 55.6 & 54.7 & 60.2 & 60.1 \\
\hline & $(49.8)$ & $(49.8)$ & $(49.0)$ & $(49.0)$ \\
\hline \multirow[t]{2}{*}{ College degree } & 22.5 & 16.7 & 52.9 & 49.2 \\
\hline & $(42.3)$ & $(37.7)$ & $(49.9)$ & $(50.0)$ \\
\hline \multirow[t]{2}{*}{ Income } & 55430.3 & 52835.1 & 83204.8 & 79568.1 \\
\hline & $(39516.7)$ & $(32679.8)$ & $(51649.2)$ & $(50114.6)$ \\
\hline \multirow[t]{2}{*}{ Age } & 41.0 & 38.6 & 39.1 & 38.4 \\
\hline & $(15.8)$ & $(20.4)$ & $(16.9)$ & $(17.3)$ \\
\hline \multirow[t]{2}{*}{ Married } & 28.6 & 60.5 & 64.1 & 62.0 \\
\hline & $(45.7)$ & $(49.5)$ & $(48.0)$ & $(48.6)$ \\
\hline \multirow[t]{2}{*}{ Child(ren) in home } & 21.4 & 65.2 & 51.2 & 51.4 \\
\hline & $(41.5)$ & $(48.2)$ & $(50.0)$ & $(50.0)$ \\
\hline \multirow[t]{2}{*}{ Total moves } & 0.4 & 0.1 & 0.2 & 0.2 \\
\hline & $(0.6)$ & $(0.3)$ & $(0.5)$ & $(0.5)$ \\
\hline Rent & 1034.0 & 934.0 & 2699.7 & 1978.7 \\
\hline
\end{tabular}




\begin{tabular}{lllll} 
& $(311.4)$ & $(224.9)$ & $(1519.6)$ & $(1313.3)$ \\
Home Value & 311806.5 & 260456.3 & $1.0 \mathrm{e}+06$ & 757341.5 \\
Hhld. Income & $(119134.6)$ & $(57758.6)$ & $(617070.9)$ & $(535532.4)$ \\
& 50611.7 & 59578.0 & 189035.8 & 175270.5 \\
\% College & $(16052.0)$ & $(12908.0)$ & $(109218.4)$ & $(111066.2)$ \\
& 10.6 & 10.7 & 40.2 & 43.9 \\
\% White & $(5.8)$ & $(4.2)$ & $(19.7)$ & $(21.5)$ \\
& 19.2 & 23.1 & 58.9 & 59.0 \\
\% Black & $(17.8)$ & $(13.7)$ & $(21.4)$ & $(22.7)$ \\
& 9.3 & 6.9 & 5.2 & 8.5 \\
\% Hispanic & $(11.7)$ & $(10.8)$ & $(5.6)$ & $(8.4)$ \\
& 63.0 & 60.7 & 20.4 & 20.0 \\
\% Asian & $(18.9)$ & $(15.1)$ & $(17.2)$ & $(20.3)$ \\
& 8.0 & 9.0 & 14.9 & 17.5 \\
$\mathrm{~N}$ & $(7.6)$ & $(6.6)$ & $(11.5)$ & $(12.4)$ \\
\hline
\end{tabular}

\section{Black}

\begin{tabular}{lllll} 
& & & Not \\
& Gentrifying & Gentrifiable & Gentrifying & Total \\
\hline Health & 3.0 & 3.1 & 3.6 & 3.3 \\
Years in gentrified tract & $(1.2)$ & $(1.1)$ & $(1.0)$ & $(1.1)$ \\
& 4.3 & 0.6 & 0.2 & 1.4 \\
Hispanic & $(3.3)$ & $(1.3)$ & $(0.9)$ & $(2.6)$ \\
& 0.0 & 0.0 & 0.0 & 0.0 \\
White & $(0.0)$ & $(0.0)$ & $(0.0)$ & $(0.0)$ \\
& 0.0 & 0.0 & 0.0 & 0.0 \\
Black & $(0.0)$ & $(0.0)$ & $(0.0)$ & $(0.0)$ \\
& 100.0 & 100.0 & 100.0 & 100.0 \\
Asian & $(0.0)$ & $(0.0)$ & $(0.0)$ & $(0.0)$ \\
& 0.0 & 0.0 & 0.0 & 0.0 \\
Women & $(0.0)$ & $(0.0)$ & $(0.0)$ & $(0.0)$ \\
\multirow{2}{*}{ College degree } & 72.4 & 67.7 & 61.1 & 68.1 \\
& $(44.8)$ & $(46.8)$ & $(48.8)$ & $(46.6)$ \\
Income & 6.0 & 6.7 & 26.5 & 16.2 \\
& $(23.9)$ & $(25.1)$ & $(44.3)$ & $(36.9)$ \\
Age & 36047.9 & 41407.5 & 52519.9 & 44901.2 \\
& $(16103.0)$ & $(19693.0)$ & $(30128.8)$ & $(26533.1)$ \\
& 37.5 & 31.1 & 33.6 & 33.1 \\
& $(16.9)$ & $(15.9)$ & $(15.8)$ & $(16.4)$ \\
& & & &
\end{tabular}




\begin{tabular}{lllll} 
Married & 18.8 & 23.1 & 31.5 & 25.6 \\
Child(ren) in home & $(39.3)$ & $(42.4)$ & $(46.6)$ & $(43.7)$ \\
& 47.1 & 51.2 & 53.3 & 52.5 \\
Total moves & $(50.2)$ & $(50.3)$ & $(50.1)$ & $(50.0)$ \\
& 0.3 & 0.2 & 0.4 & 0.3 \\
Rent & $(0.6)$ & $(0.5)$ & $(0.7)$ & $(0.6)$ \\
& 1298.1 & 1021.1 & 2476.5 & 1364.1 \\
Home Value & $(405.9)$ & $(338.0)$ & $(2143.3)$ & $(1256.8)$ \\
& 377685.7 & 262363.7 & 673778.9 & 391617.9 \\
Hhld. Income & $(125919.3)$ & $(95349.2)$ & $(605965.9)$ & $(357019.8)$ \\
& 54508.0 & 53394.1 & 158090.0 & 103649.5 \\
\% College & $(16414.6)$ & $(14542.8)$ & $(143623.1)$ & $(112655.4)$ \\
& 5.8 & 5.2 & 24.2 & 30.7 \\
\% White & $(3.9)$ & $(3.0)$ & $(14.2)$ & $(25.6)$ \\
& 4.0 & 4.3 & 31.4 & 25.2 \\
\% Black & $(6.7)$ & $(9.3)$ & $(21.0)$ & $(22.2)$ \\
& 26.8 & 30.7 & 17.7 & 26.5 \\
\% Hispanic & $(15.2)$ & $(15.5)$ & $(15.6)$ & $(16.0)$ \\
\% Asian & 66.7 & 62.6 & 33.8 & 36.6 \\
N & $(14.5)$ & $(13.8)$ & $(18.2)$ & $(28.4)$ \\
\hline
\end{tabular}

\section{Asian/Other}

\begin{tabular}{lcccc} 
& & & Not \\
& Gentrifying & Gentrifiable & Gentrifying & Total \\
\hline Health & 3.3 & 3.3 & 3.7 & 3.6 \\
& $(1.2)$ & $(0.8)$ & $(1.0)$ & $(1.0)$ \\
Years in gentrified tract & 4.0 & 0.4 & 0.1 & 0.6 \\
& $(2.9)$ & $(1.5)$ & $(0.7)$ & $(1.7)$ \\
Hispanic & 0.0 & 0.0 & 0.0 & 0.0 \\
\multirow{2}{*}{ White } & $(0.0)$ & $(0.0)$ & $(0.0)$ & $(0.0)$ \\
& 0.0 & 0.0 & 0.0 & 0.0 \\
Black & $(0.0)$ & $(0.0)$ & $(0.0)$ & $(0.0)$ \\
& 0.0 & 0.0 & 0.0 & 0.0 \\
Asian & $(0.0)$ & $(0.0)$ & $(0.0)$ & $(0.0)$ \\
& 100.0 & 100.0 & 100.0 & 100.0 \\
& $(0.0)$ & $(0.0)$ & $(0.0)$ & $(0.0)$
\end{tabular}




\begin{tabular}{|c|c|c|c|c|}
\hline Women & $\begin{array}{l}63.7 \\
(48.3)\end{array}$ & $\begin{array}{l}63.9 \\
(48.1)\end{array}$ & $\begin{array}{l}62.4 \\
(48.5)\end{array}$ & $\begin{array}{l}63.1 \\
(48.3)\end{array}$ \\
\hline College degree & $\begin{array}{l}25.0 \\
(44.1)\end{array}$ & $\begin{array}{l}7.7 \\
(27.2)\end{array}$ & $\begin{array}{l}48.1 \\
(50.1)\end{array}$ & $\begin{array}{l}42.1 \\
(49.5)\end{array}$ \\
\hline Income & $\begin{array}{l}38192.6 \\
(22574.1)\end{array}$ & $\begin{array}{l}34577.8 \\
(17381.8)\end{array}$ & $\begin{array}{l}59912.7 \\
(29465.2)\end{array}$ & $\begin{array}{l}54980.0 \\
(29035.6)\end{array}$ \\
\hline Age & $\begin{array}{l}38.8 \\
(17.5)\end{array}$ & $\begin{array}{l}31.1 \\
(16.7)\end{array}$ & $\begin{array}{l}35.8 \\
(17.6)\end{array}$ & $\begin{array}{l}34.6 \\
(17.5)\end{array}$ \\
\hline Married & $\begin{array}{l}42.4 \\
(50.2)\end{array}$ & $\begin{array}{l}50.0 \\
(51.2)\end{array}$ & $\begin{array}{l}61.9 \\
(48.7)\end{array}$ & $\begin{array}{l}58.1 \\
(49.4)\end{array}$ \\
\hline Child(ren) in home & $\begin{array}{l}36.4 \\
(48.9)\end{array}$ & $\begin{array}{l}59.1 \\
(50.3)\end{array}$ & $\begin{array}{l}54.8 \\
(49.9)\end{array}$ & $\begin{array}{l}52.9 \\
(50.0)\end{array}$ \\
\hline Total moves & $\begin{array}{c}0.2 \\
(0.5)\end{array}$ & $\begin{array}{c}0.3 \\
(0.5)\end{array}$ & $\begin{array}{c}0.2 \\
(0.5)\end{array}$ & $\begin{array}{c}0.2 \\
(0.5)\end{array}$ \\
\hline Rent & $\begin{array}{l}984.3 \\
(254.9)\end{array}$ & $\begin{array}{l}876.0 \\
(233.5)\end{array}$ & $\begin{array}{l}2633.2 \\
(2570.7)\end{array}$ & $\begin{array}{l}1776.4 \\
(1815.0)\end{array}$ \\
\hline Home Value & $\begin{array}{l}345188.4 \\
(78688.7)\end{array}$ & $\begin{array}{l}237584.9 \\
(80085.6)\end{array}$ & $\begin{array}{l}802097.5 \\
(731753.5)\end{array}$ & $\begin{array}{l}567963.4 \\
(525322.4)\end{array}$ \\
\hline Hhld. Income & $\begin{array}{l}47315.7 \\
(14078.7)\end{array}$ & $\begin{array}{l}49866.8 \\
(14670.6)\end{array}$ & $\begin{array}{l}174964.5 \\
(158246.8)\end{array}$ & $\begin{array}{l}149946.4 \\
(150465.6)\end{array}$ \\
\hline$\%$ College & $\begin{array}{l}11.6 \\
(5.5)\end{array}$ & $\begin{array}{c}7.8 \\
(4.6)\end{array}$ & $\begin{array}{l}32.2 \\
(14.2)\end{array}$ & $\begin{array}{l}38.8 \\
(21.5)\end{array}$ \\
\hline$\%$ White & $\begin{array}{l}11.6 \\
(8.4)\end{array}$ & $\begin{array}{l}11.4 \\
(10.7)\end{array}$ & $\begin{array}{l}39.4 \\
(18.0)\end{array}$ & $\begin{array}{l}40.2 \\
(20.9)\end{array}$ \\
\hline$\%$ Black & $\begin{array}{l}7.6 \\
(10.6)\end{array}$ & $\begin{array}{l}12.8 \\
(11.8)\end{array}$ & $\begin{array}{c}6.0 \\
(5.1)\end{array}$ & $\begin{array}{l}11.2 \\
(9.5)\end{array}$ \\
\hline$\%$ Hispanic & $\begin{array}{l}71.6 \\
(12.2)\end{array}$ & $\begin{array}{l}67.2 \\
(12.9)\end{array}$ & $\begin{array}{l}26.5 \\
(16.0)\end{array}$ & $\begin{array}{l}26.1 \\
(23.6)\end{array}$ \\
\hline$\%$ Asian & $\begin{array}{c}8.8 \\
(6.6)\end{array}$ & $\begin{array}{c}8.2 \\
(9.3)\end{array}$ & $\begin{array}{l}27.4 \\
(12.9)\end{array}$ & $\begin{array}{l}28.9 \\
(15.8)\end{array}$ \\
\hline $\mathrm{N}$ & 14 & 13 & 117 & 144 \\
\hline
\end{tabular}

Note: All dollar amounts are standardized to 2012. Standard deviations in parenthesis. 


\section{APPENDIX C}

Changes in Duration of Gentrification, Both Waves (Individual Fixed Effects, unimputed)

\begin{tabular}{|c|c|c|}
\hline VARIABLES & $\begin{array}{l}(1) \\
\text { All }\end{array}$ & $\begin{array}{l}(2) \\
\text { All } \\
\end{array}$ \\
\hline Years $r$ lived in gentrified tract & $\begin{array}{c}0.070 * * \\
(0.025)\end{array}$ & $\begin{array}{c}0.005 \\
(0.125)\end{array}$ \\
\hline \multicolumn{3}{|c|}{ Race and gentrification duration interaction $(\operatorname{Ref}=$ Whites $)$} \\
\hline Hispanic $\mathrm{x}$ Years in gentrified tract & & $\begin{array}{c}0.064 \\
(0.127)\end{array}$ \\
\hline Black $x$ Years in gentrified tract & & $\begin{array}{c}0.082 \\
(0.141)\end{array}$ \\
\hline Asian/other $\mathrm{x}$ Years in gentrified tract & & $\begin{array}{c}0.076 \\
(0.149)\end{array}$ \\
\hline \multicolumn{3}{|l|}{ Education (Ref=less than HS) } \\
\hline HS Grad & $\begin{array}{c}0.109 \\
(0.328)\end{array}$ & $\begin{array}{c}0.101 \\
(0.331)\end{array}$ \\
\hline Some College & $\begin{array}{c}-0.029 \\
(0.370)\end{array}$ & $\begin{array}{c}-0.047 \\
(0.377)\end{array}$ \\
\hline College or more & $\begin{array}{c}0.003 \\
(0.410)\end{array}$ & $\begin{array}{l}-0.025 \\
(0.419)\end{array}$ \\
\hline Log Individual Income & $\begin{array}{l}-0.008 \\
(0.075)\end{array}$ & $\begin{array}{c}-0.008 \\
(0.075)\end{array}$ \\
\hline Age & $\begin{array}{l}-0.008 \\
(0.012)\end{array}$ & $\begin{array}{c}-0.008 \\
(0.012)\end{array}$ \\
\hline Unmarried (ref. $=$ married) & $\begin{array}{c}0.119 \\
(0.143)\end{array}$ & $\begin{array}{c}0.118 \\
(0.143)\end{array}$ \\
\hline Child(ren) live in household & $\begin{array}{c}0.111 \\
(0.120)\end{array}$ & $\begin{array}{c}0.110 \\
(0.120)\end{array}$ \\
\hline Constant & $\begin{array}{c}3.661 * * * \\
(0.922)\end{array}$ & $\begin{array}{c}3.667 * * * \\
(0.925)\end{array}$ \\
\hline Individual Fixed Effects & & \\
\hline Observations & 2,282 & 2,282 \\
\hline Respondents & 1,141 & 1,141 \\
\hline
\end{tabular}

Standard errors in parentheses

$* * * \mathrm{p}<0.001, * * \mathrm{p}<0.01, * \mathrm{p}<0.05$ 


\section{FOOTNOTES}

${ }^{1}$ I use the term "Hispanic" to refer to Latinx communities throughout this paper to maintain consistency with Census categories.

${ }^{2}$ See Appendix C

${ }^{3}$ I employ 1990 as the threshold of gentrifiability for two important reasons. First, the residential history for many residents begins in 1998. As a result, the 1990 threshold captures an element of historic disinvestment in the neighborhood. Second, the use of a threshold that is several years before the beginning of the residential history, rather than a more contemporaneous measure, requires fewer assumptions concerning the speed at which gentrification takes place. If, for instance, gentrifiability were based upon disinvestment in the previous year, this assumes that gentrification can occur extremely rapidly. The preponderance of gentrification research, however, demonstrates that this process of neighborhood change occurs at a slower pace than this.

${ }^{4}$ Because this measure of gentrification relies on census data, I cannot be certain whether neighborhood increases in college attendance, income, and home value are different residents, or simply the same residents who increase their socioeconomic status. Descriptive statistics later in this paper demonstrate that the racial composition of these neighborhoods also changes substantially, suggesting that the changes in SES that we observe are a result of changes in the composition of residents, rather than rises in SES of long term residents.

${ }^{5}$ In this analysis, the primary gentrification measure indicates the total number of years a resident has lived in a gentrifying neighborhood up through their first and second interviews. Gentrification occurs in stages, with some neighborhoods having just begun the process, and others experiencing significant levels of capital investment and more visible demographic 
changes (Hwang and Sampson 2014; Wyly and Hammel 2004). As a result, it is unclear what precisely a measure of gentrification that sums the total number of years lived in a gentrifying tract captures. For some, the duration measure indicates that an individual has lived in the same gentrifying tract for many years, experiencing the beginning through the late stages of gentrification. For others, the duration measure may capture residence in multiple tracts during the same beginning stage of gentrification.

The correlation between duration of exposure to gentrification and total number of times an individual has moved gives some insight into this question of the extent to which duration of exposure should be employed as a proxy for the range of stages of gentrification an individual has experienced. A high correlation between years of exposure to gentrification and total moves would suggest that the greater the number of years in a gentrifying tract, the greater the number of different tracts in which the respondent has lived. Conversely, a low correlation indicates that respondents are more likely to have been exposed to all of their years of gentrification in one neighborhood. The minuscule correlation between duration of gentrification and total moves $(0.0485)$ provides some justification for the use of duration of exposure as a proxy for experience with a broad array of stages of gentrification in a particular census tract.

${ }^{6}$ Tables are available upon request.

${ }^{7}$ I also perform the analysis controlling for the tract-level characteristics, and results do not differ substantively.

${ }^{8}$ To interrogate the extent to which the experience of stayers differs from the full sample, I also perform this analysis on a stratified sample of stayers in robustness checks. This stratified sample includes only those who remain in gentrifying neighborhoods throughout the duration of their 
residential histories. Results from this analysis do not rise to the level of statistical significance. Tables are available upon request.

${ }^{9}$ Appendix A presents within- and between-panel variation for the covariates included in the analysis. This table demonstrates that, as mentioned in the Analytic Strategy section, there is no within-panel variation for race and sex. Put differently, a respondent's race and sex are constant over time in this sample. There is in fact variation over time in the other variables included in the model. For instance, the within-panel standard deviation for self-rated health is 0.5 on a 5-point scale. Income changes by more than $\$ 8,500$ on average. This table suggests that there is significant variation within individuals over time to warrant the use of a fixed effects model. 10 Too few tracts were gentrifying in 1991 to compare to 2008. As a result, the first year of descriptive statistics is in 1992.

${ }^{11}$ All dollar amounts are in 2012 dollars.

12 Although the reference category for the interaction between years of exposure to gentrification and race is whites, I also test the null hypothesis that the coefficients for Black and Hispanic residents are equal. I fail to reject this null hypothesis at $\mathrm{p}<0.05$, indicating that the coefficients for these 2 groups are statistically indistinguishable. I included immigrant status as a control in other models, and this did not substantively alter results.

${ }^{13}$ See Appendix C.

${ }^{14}$ I perform a similar analysis in which I define stability as a tract having remained in the same decile of rent and percent of people with a college degree, or remained in the same decile of median household income and percentage of people with a college degree in each year between 1990 and 2008. These results were also not statistically significant. 